\title{
The Roles of Neurotrophins in Traumatic Brain Injury
}

\author{
Ping-Hung Lin ${ }^{1,+} \mathbb{D}$, Lu-Ting Kuo ${ }^{2,+}$ 迆 and Hui-Tzung Luh ${ }^{3,4,5, *(\mathbb{D})}$ \\ 1 Department of Medical Education, School of Medicine, National Taiwan University, Taipei 100, Taiwan; \\ b03401063@ntu.edu.tw \\ 2 Division of Neurosurgery, Department of Surgery, National Taiwan University Hospital, Taipei 100, Taiwan; \\ ltkuo@ntu.edu.tw \\ 3 Department of Neurosurgery, Shuang Ho Hospital, Taipei Medical University, New Taipei City 235, Taiwan \\ 4 Taipei Neuroscience Institute, Taipei Medical University, New Taipei City 235, Taiwan \\ 5 Graduate Institute of Clinical Medicine, National Taiwan University, Taipei 100, Taiwan \\ * Correspondence: $17260 @$ s.tmu.edu.tw; Tel.: +886-956279587 \\ + These authors contributed equally to this work.
}

check for

updates

Citation: Lin, P.-H.; Kuo, L.-T.; Luh, H.-T. The Roles of Neurotrophins in Traumatic Brain Injury. Life 2022, 12 , 26. https://doi.org/10.3390/ life12010026

Academic Editors: Marianna Flora Tomasello, Angela

Maria Amorini and

Francesco Attanasio

Received: 12 November 2021

Accepted: 21 December 2021

Published: 24 December 2021

Publisher's Note: MDPI stays neutral with regard to jurisdictional claims in published maps and institutional affiliations.

Copyright: () 2021 by the authors Licensee MDPI, Basel, Switzerland. This article is an open access article distributed under the terms and conditions of the Creative Commons Attribution (CC BY) license (https:/ / creativecommons.org/licenses/by/ $4.0 /)$.

\begin{abstract}
Neurotrophins are a collection of structurally and functionally related proteins. They play important roles in many aspects of neural development, survival, and plasticity. Traumatic brain injury (TBI) leads to different levels of central nervous tissue destruction and cellular repair through various compensatory mechanisms promoted by the injured brain. Many studies have shown that neurotrophins are key modulators of neuroinflammation, apoptosis, blood-brain barrier permeability, memory capacity, and neurite regeneration. The expression of neurotrophins following TBI is affected by the severity of injury, genetic polymorphism, and different post-traumatic time points. Emerging research is focused on the potential therapeutic applications of neurotrophins in managing TBI. We conducted a comprehensive review by organizing the studies that demonstrate the role of neurotrophins in the management of TBI.
\end{abstract}

Keywords: neurotrophins; traumatic brain injury; nerve growth factor; brain-derived neurotrophic factor; NT-3; NT-4/5

\section{Biochemistry of Neurotrophins}

Neurotrophins are a collection of structurally and functionally related proteins. They undergo proteolytic processes from proneurotrophins (precursor proteins) that possess a Cterminal mature domain and an $\mathrm{N}$-terminal prodomain [1]. The prodomains ensure proper protein folding and dimerization, whereas the mature domains play a role in the biological effects of neurotrophins [2]. They were first discovered as physiological regulators of the sympathetic and sensory neurons that modulate neuronal survival, function, and development not only within the peripheral nervous system (PNS) but also in the central nervous system (CNS) [3]. These factors control axonal plasticity, neuronal survival, and several synaptic functions, including neurotransmitter availability [4]. Many neurotrophic factors such as the basic fibroblast growth factor (bFGF), ciliary neurotrophic factor (CNTF), glial cell line-derived neurotrophic factor (GDNF), insulin growth factors (IGFs), transforming growth factors (TGFs), and tumor necrosis factors (TNFs) can attenuate neuronal injury and regulate the differentiation, survival, and maintenance of nerve cells [5]. However, the term "neurotrophin" is more commonly used to refer to four structurally related biomolecules only. In this review, we will primarily focus on the characteristics of the four neurotrophins in the human body: nerve growth factor (NGF), brain-derived neurotrophic factor (BDNF), neurotrophin 3 (NT-3), and neurotrophin 4 (NT-4), sometimes known as neurotrophin 5 (NT-5) (NT-4/5) [6].

Neurotrophins can bind to two separate classes of receptors: p75 neurotrophin receptor $\left(\mathrm{p} 75^{\mathrm{NTR}}\right)$ and tropomyosin receptor kinase (Trk) receptors. All members of the mature neurotrophin family have a lower affinity for the $\mathrm{p} 75^{\mathrm{NTR}}$ receptor than proneurotrophins [7]. 
Meanwhile, individual neurotrophins activate corresponding Trk receptors with high specificity and affinity, with NGF binding to TrkA, BDNF and NT-4/5 binding to TrkB, and NT-3 binding to TrkC [8-10]. TrkB binds BDNF and NT-4/5 more strongly than NT-3. TrkC binds NT-3 more tightly than TrkB [11]. Furthermore, Verdi et al. showed that p75 ${ }^{\mathrm{NTR}}$ augments the response of TrkA to NGF [12,13]. In fact, Ip et al. discovered that a neuronal environment limits the ability of Trk receptors to bind to their specifically non-preferred neurotrophin ligands [14].

The complex interplay between the p $75^{\mathrm{NTR}}$ and Trk receptors for neurotrophin signaling has been identified and occurs in several ways [15]. Hempstead et al. discovered that the co-expression of the Trk proto-oncogene and $\mathrm{p} 75^{\mathrm{NTR}}$ is required for the development of high-affinity NGF-binding sites [16]. Benedetti et al. discovered that a proper p $75^{\mathrm{NTR}}$ /Trk receptor ratio was essential for establishing high-affinity sites [17]. Bibel et al. further demonstrated the close proximity of $\mathrm{p} 75^{\mathrm{NTR}}$ and Trk receptors within cell membranes by immunoprecipitation in transfected cells and suggested that the signaling pathways they initiated would interact soon after their activation [15].

When neurotrophins bind to Trk receptors, they dimerize the receptor and autophosphorylate tyrosine residues, activating downstream signaling cascades [18]. The phosphatidylinositol 3 kinase (PI3K) / protein kinase B (Akt) signaling pathway, the Ras / mitogenactivated protein kinase (Ras/MAPK) signaling network, and the phospholipase C (PLC) signaling pathways are known to be activated or increased $[9,19,20]$. Some rapid signaling that controls a range of cellular activities, such as membrane excitability, synaptic transmission, and activity-dependent synaptic plasticity, is primarily mediated by Trk receptor interactions with ion channels and ionotropic receptors in the cell membrane [21].

p $75^{\mathrm{NTR}}$, the pan-neurotrophin receptor, plays various complex roles in regulating cell survival, neurodegeneration, and cell death. It initiates pro-apoptotic cascades through different signaling pathways [22], including the nuclear factor (NF)- $k B$ pathway, the Jun kinase pathway, and the activity of Rho, which participate in neuronal survival, apoptosis, and growth cone motility, respectively $[8,19]$. While p $75^{\text {NTR }}$ combines with sortilin, a co-receptor for neurotrophins, and forms heterodimers, apoptotic pathways can be activated $[23,24]$. Furthermore, p $75^{\mathrm{NTR}}$, in conjunction with sortilin, can increase the binding capability of proneurotrophins such as pro-NGF, a molecule involved in the death of oligodendrocytes, corticospinal neurons, and spinal motor neurons in the injured state $[6,7,25,26]$. As a result, the relative amount of pro-neurotrophins and mature neurotrophins or the number of Trk and $\mathrm{p} 75^{\mathrm{NTR}}$ receptors determines whether apoptotic or neurotrophic effects are generated [27].

The $\mathrm{p} 75^{\mathrm{NTR}}$ can also limit ligand-induced Trk receptor ubiquitination, postpone Trk receptor degradation, and therefore prolong the duration of Trk receptor-dependent signaling $[28,29]$. Additionally, p $75^{\mathrm{NTR}}$ can activate the Akt pathway, which plays an important role in the Trk-mediated neurotrophic signaling pathway, to support the pro-survival function, contrary to the popular hypothesis that $\mathrm{p} 75^{\mathrm{NTR}}$ is only responsible for neuronal cell apoptosis $[4,30]$.

\section{Neurotrophins and Traumatic Brain Injury}

In response to the brain damage caused by traumatic brain injury (TBI), the brain can heal itself through a variety of compensatory processes known as neuroplasticity [31]. During post-traumatic brain remodeling processes, altered growth factor signaling, synaptogenesis, angiogenesis, neuron cell proliferation, gliogenesis, and cell structural changes can remodel the brain to improve functional recovery [32-34].

The choroid plexus reactively secretes neuropeptides that are consecutively distributed through the cerebrospinal fluid (CSF) to the traumatic region $[35,36]$ to facilitate neurogenesis and parenchymal healing and restore cognitive ability [37-40]. Interestingly, how the signal transduction and homeostatic adjustment from a remote brain injury are transmitted to the choroid plexus, which is not directly destroyed by trauma, remains unknown. The modulating neuropeptides include CNTF, transforming growth factor $\beta 1$ (TGF- $\beta 1$ ) [41], 
fibroblast growth factor 2 (FGF2), epidermal growth factor (EGF), vascular endothelial growth factor (VEGF), NGF, IGF [36], GDNF [42-44], BDNF, and pituitary adenylate cyclase-activating polypeptide (PACAP) [45-51].

Studies of TBI and stroke have provided substantial evidence that neuropeptides, including neurotrophins, given exogenously to the CSF strengthen the protective effect and induce neuronal repair, regeneration, and synaptic sprouting. Numerous exogenously delivered CSF peptides, such as GDNF, PACAP, VEGF, IGF, FGF2, NGF, and BDNF, showed a significantly improved neurogenic capacity weakened in TBI $[40,52,53]$. For example, Sharma et al. found that the intracerebroventricular administration of BDNF, together with GDNF and IGF-1, significantly reduced the blood-brain barrier (BBB) and blood-CSF barrier (BCSFB) breakdown, cellular/tissue injuries, and brain edema formation in a rat model following whole-body hyperthermia, which causes the breakdown of the choroid plexus and was used to stimulate the mechanism of TBI in experiments [39].

Both human and murine studies have suggested that pro-neurotrophins are significantly upregulated following brain injuries or degenerative diseases, and the binding of these proteins to $\mathrm{p} 75^{\mathrm{NTR}}$ may control programmed neuronal cell death in injured or degenerative conditions [54-56]. The levels of endogenous neurotrophic factors are also affected by various kinds of CNS injuries, including TBI as well as other degenerative diseases [5]. An increase in their expression is thought to be one of the mechanisms for providing neuroprotection, neuronal repair, and neurogenesis following injury [57]. The expression of these growth factors is exemplified by NT-3, NT-4/5, NGF, BDNF, IGFs, bFGF, TGFs, and TNFs [58-60] (Table 1). Studies on these neuroprotective agents show that they reduce inflammation, free radical production, and cytoskeleton damage, whereas excitatory amino acids and inflammatory cytokines produced early in the secondary injury cascade disrupt intracellular calcium homeostasis [58]. Some studies also revealed that neurotrophins may serve as sensitive biomarkers for clinical outcomes of patients with TBI $[61,62]$.

A number of recent investigations have indicated that the abnormalities in signaling pathways that are expected to have a role in many clinical conditions are important targets in neurotrophin signaling [63]. Because PI3K/AKT signaling is a powerful mechanism for inhibiting the activation of stress kinases and GSK-b, the stimulation of PI3K/AKT signaling by neurotrophin mimetics may provide neuroprotection [64]. For example, the flavonoid 7,8-dihydroxyflavone, a small TrkB agonist that mimics BDNF action, was found to have benefits comparable to those of BDNF in boosting neuronal survival and regeneration after TBI $[65,66]$. Because of its longer half-life and considerably smaller molecular size when compared to BDNF, it can cross the BBB; thus, it can be used in non-invasive clinical applications [67].

Table 1. Responses of neurotrophins after TBI.

\begin{tabular}{|c|c|c|c|c|c|}
\hline Neurotrophins & Site & $\begin{array}{l}\text { Level of } \\
\text { Expression }\end{array}$ & Response & Remark/Note & Reference \\
\hline \multirow{4}{*}{ NGF } & \multirow{3}{*}{ Hippocampus in rats } & \multirow{3}{*}{ Protein } & \multirow{3}{*}{ Biphasic } & Increase: $6 \mathrm{~h}$ & \multirow{3}{*}{ [68] } \\
\hline & & & & Decline: 7 days & \\
\hline & & & & $\begin{array}{l}\text { Second rise: } \\
14 \text { days }\end{array}$ & \\
\hline & $\begin{array}{l}\text { hippocampus in rats with } \\
\text { CSF dissemination }\end{array}$ & Protein & Increase & None & [68] \\
\hline
\end{tabular}


Table 1. Cont.

\begin{tabular}{|c|c|c|c|c|c|}
\hline Neurotrophins & Site & $\begin{array}{l}\text { Level of } \\
\text { Expression }\end{array}$ & Response & Remark/Note & Reference \\
\hline \multirow{7}{*}{$\mathrm{BDNF}$} & Hippocampus in rats & $\begin{array}{l}\text { mRNA of BDNF } \\
\text { and mRNA of TrkB }\end{array}$ & Increase & None & [69] \\
\hline & $\begin{array}{l}\text { Cortex ipsilateral to the } \\
\text { lesion site and the } \\
\text { bilateral dorsal } \\
\text { hippocampus in rats }\end{array}$ & mRNA & Increase & None & {$[70]$} \\
\hline & $\begin{array}{l}\text { Hippocampus ipsilateral } \\
\text { to the lesion site in rats }\end{array}$ & mRNA & Decrease & None & {$[71]$} \\
\hline & \multirow{3}{*}{$\begin{array}{l}\text { Hippocampus } \\
\text { contralateral to the lesion } \\
\text { site in rats }\end{array}$} & mRNA & Increase & $\begin{array}{c}\text { Sustained for } 2 \\
\text { weeks }\end{array}$ & {$[71]$} \\
\hline & & Protein & Decrease & Post-injury $24 \mathrm{~h}$ & [72] \\
\hline & & & $\begin{array}{l}\text { Same as post-TBI } \\
\text { baseline }\end{array}$ & Post-injury $36 \mathrm{~h}$ & [72] \\
\hline & $\begin{array}{l}\text { Hippocampus and } \\
\text { dentate gyrus in rats }\end{array}$ & $\begin{array}{l}\text { mRNA of BDNF } \\
\text { and mRNA of TrkB }\end{array}$ & Increase & None & [73] \\
\hline \multirow{3}{*}{ NT-3 } & Hippocampus in rats & mRNA & Decrease & None & [69] \\
\hline & $\begin{array}{l}\text { Dentate gyrus and cornu } \\
\text { ammonis } 2 \text { regions of the } \\
\text { hippocampus in rats }\end{array}$ & mRNA and protein & Decrease & $\begin{array}{l}\text { In the first } 12-24 \mathrm{~h} \\
\text { following TBI }\end{array}$ & {$[74,75]$} \\
\hline & Rat brain & mRNA & $\begin{array}{l}\text { Same as post-TBI } \\
\text { baseline }\end{array}$ & None & {$[70]$} \\
\hline NT-4/5 & $\begin{array}{l}\text { Injured cortex and } \\
\text { hippocampus in rats }\end{array}$ & Protein & Increase & $\begin{array}{l}\text { In the acute period } \\
\text { (within } 3 \text { days) }\end{array}$ & {$[60]$} \\
\hline
\end{tabular}

\subsection{Nerve Growth Factor}

In the early 1950s, Levi-Montalcini revealed that NGF may control the survival and maturation of developing PNS neurons [3]. Since then, NGF has become one of the most well-known members of the neurotrophin family for promoting axonal sprouting, dendritic formation, and cell body expansion in neural systems, and studies about relevant therapeutics also emerged afterwards [76-78].

In response to TBI, NGF in the hippocampus is quickly upregulated and exhibits a biphasic response. In a controlled cortical impact damage model in rats, DeKosky et al. found that NGF increased at $6 \mathrm{~h}$, dropped at 7 days, and then increased again at 14 days [68]. They also showed that NGF participated in initializing post-TBI antioxidant reactions in rats by activating several antioxidant enzymes, including the upregulation of catalase (CAT), glutathione peroxidase (GPx), and the downregulation of superoxide dismutase (SOD) [68]. Dixon et al. concluded that post-TBI NGF elevation in the hippocampus and its dissemination through CSF help restore cholinergic neurotransmission and cognitive function, particularly spatial memory, in a rat TBI model generated using a controlled cortical impact injury device [79]. Hicks et al. discovered that a mild lateral fluid percussion brain injury in rats induced significant increases in BDNF and TrkB mRNAs as well as a decrease in NT-3 mRNA, demonstrating that even mild TBI differentially alters neurotrophin and neurotrophin receptor levels in the hippocampus [69].

Clinically, NGF concentrations in the CSF have a significant correlation with the severity of TBI and can serve as a biomarker for predicting neurological outcomes. Chiaretti et al. conducted an observational study indicating that higher NGF and lower interleukin (IL) $1 \beta$ concentrations at $2 \mathrm{~h}$ after TBI correlated significantly with favorable neurological outcomes in children with TBI, whereas no outcome correlation was found for IL-6, BDNF, or GDNF expression [61]. Meanwhile, NGF may be able to trigger inflammatory cascades 
with negative consequences on surrounding tissues because NGF levels are increased in many inflammatory disorders such as chronic arthritis and multiple sclerosis [80,81]. NGF is well-known for its complex involvement in nociceptive processing [82]. Dai et al. discovered in a rat model of neuropathic pain that inhibiting TAK1-MAPK-/NF- $\mathrm{B}$ signaling in the periphery reduced neuropathic pain [83]. Despite the abundance of literature on NGFmediated neuropathic pain modulation, the specific signaling pathways downstream of NGF receptor activation that produce nociception are complex and poorly understood [82].

\subsection{Brain-Derived Neurotrophic Factor}

BDNF is the most abundant neurotrophin in the CNS [84] and the most widely studied, owing to its potential effects and wide distribution in the brain [85]. The coordination of the BDNF and TrkB receptors governs a wide range of neural activities, including neuronal survival, differentiation, migration, axonal sprouting, synaptogenesis, plasticity, and the enhancement of long-term potentiation (LTP), which influences learning and memory [86-88]. Growing studies focusing on BDNF have emerged, but there are discrepancies among the results of BDNF expression at different post-injury times, regions in the CNS, genetic polymorphisms, and clinical outcomes [89-91].

\subsubsection{Divergent Expression of BDNF}

In terms of BDNF expression in various CNS areas, Yang et al. discovered that BDNF mRNA expression was considerably enhanced in the cortex ipsilateral to the injured side and bilateral dorsal hippocampus in a rat model following TBI caused by a controlled lateral cortical impact [70]. In another rat model, however, following a TBI caused by the controlled penetration of a 2-mm-thick needle-shaped item, Rostami et al. found that BDNF mRNA expression was reduced in the hippocampus ipsilateral to the lesion, but it was increased on the contralateral side [71]. As for discrepancies in post-injury time course, the level of BDNF was significantly down-regulated at $24 \mathrm{~h}$ post-injury and returned to the level with no significant difference at $36 \mathrm{~h}$ post-injury compared with $0 \mathrm{~h}$ post-injury [72]. Nonetheless, Rostami et al. discovered that the increase in BDNF mRNA expression in the hippocampus lasted for 2 weeks following TBI [71]. Merlio et al. demonstrated that the mRNA expression level of the TrkB receptor is similarly upregulated in the same time course with BDNF in the hippocampus and dentate gyrus from a rat model with electrical stimulation with a rapid kindling paradigm in the hippocampus [73]. The surge of BDNF and its corresponding receptor indicated that BDNF has the capacity to attenuate secondary cell injuries and protect the neuronal function following TBI [5]. Distinct regulatory signaling cascades between cortisol and BDNF may influence secondary injury mechanisms after TBI and predict clinical outcomes. Munoz et al. conducted a prospective cohort study with 117 patients and discovered that BDNF in the CSF is related to patients' cortisol levels, which can strongly predict a 6-month mortality after severe TBI. These findings suggest that hormone and neurotrophin levels may be related to the degree of neurological damage [62].

\subsubsection{Single-Nucleotide Polymorphism of BDNF}

The BDNF protein possesses a single-nucleotide polymorphism (SNP) site at rs6265, at the 66-amino acid position, which results in the replacement of wildtype Val with Met (Val66Met, valine to methionine) [92]. Although other SNPs of BDNF such as rs71244, rs1519480, and rs1153659 have been reported to influence the outcome after TBI, the most studied polymorphism of BDNF in humans is rs6265 (Val66Met) [89]. The frequency of the Met66 allele is approximately $25-32 \%$ in Caucasian populations and $40-50 \%$ in Asian populations [93]. Egan et al. found that when Val66 (vBDNF) in the BDNF sequence is substituted with a Met (mBDNF), the depolarization-dependent BDNF production in human hippocampal neurons is severely reduced [94]. Consequently, mBDNF tends to accumulate in the soma, whereas vBDNF accumulates in punctate vesicles in the dendrites. Neurons 
secrete $\mathrm{vBDNF}$ but not $\mathrm{mBDNF}$ in response to activity. The activity-dependent release of BDNF drives LTP [95]; thus, Val66Met SNP carriers have impaired neuroplasticity [94].

Giarratana et al. discovered that injured Val66Met carriers had a larger inflammatory volume, increased apoptosis, and gliosis at 1 day or 21 days post-TBI in a mouse model following repeated mild TBI utilizing a lateral fluid percussion technique. In terms of apoptosis-inducing pro-BDNF (precursor) and survival-inducing mature BDNF levels in the hippocampus, the Val66Met carriers had a lower total BDNF and a higher pro/mature ratio of BDNF than the wild-type Val66Val carriers. According to animal research, the Val66Met SNP is a risk factor for poor outcomes after mild TBI [92].

As to the influence of the Val66Met SNP in mild TBI human cases, Wang et al. found more depression and anxiety in Val66Met carriers at 1 and 6 weeks post-TBI from a 192-cases cohort [96].

However, in severe TBI cases from phase 3 of the Vietnam Head Injury Study (VHIS) registry, the Val66Met polymorphism partially helped the neurological adaptation and promoted the recovery of executive functions such as intelligence, memory, and processing speed in patients with severe TBI $[97,98]$. It is worth mentioning that the brain function was assessed in these veterans at very long-term time points, up to more than 40 years after TBI. Val66Met carriers secrete less mature BDNF and proBDNF (the precursor of BDNF) in response to activity. mBDNF is protective after severe TBI, suggesting that the apoptotic action of proBDNF overcomes the survival signaling of mature BDNF in this context [90].

\subsection{Neurotrophin 3}

NT-3 is a neurotrophin family member with a remarkable number of amino acid identities and four variable domains that are structurally linked to other neurotrophins such as NGF and BDNF $[99,100]$. NT-3, a trophic factor for sympathetic and sensory neurons [101], regulates neuronal survival, differentiation, and maintenance in the PNS and CNS [102-105]. NT-3 exerts functional effects by attaching to the TrkC receptor with high affinity [106].

Endogenous NT-3 protein levels and NT-3 mRNA expression are considerably lower in the first 12-24 $\mathrm{h}$ after TBI [107,108], including the dentate gyrus [74] and cornu ammonis (CA) 2 region [75] of the hippocampus, indicating a negative function of NT-3 in the early phase of injury [109]. Endogenous NT-3, according to Bates et al., accelerates neuronal death in cortical cells induced by oxygen-glucose deprivation, potentially by increasing reactive oxygen species [110]. The downregulation of NT-3 is most likely a protective mechanism.

However, reverse results have been reported in some rat models. One study showed that TBI proceeded without changes in NT-3 mRNA expression [70], whereas another study showed that, in corticospinal neurons, exogenous NT-3 significantly prevented the axotomy-induced death of neuronal cells, showing the protective and beneficial roles of NT-3 [111]. Furthermore, in rat models, the topical administration of NT-3 decreased brain edema and BBB permeability while improving the consciousness level following TBI [107].

As for studies focused on human diseases in the CNS, recombinant NT-3 administered in a specific regimen has been proven to be safe without serious complications in human bodies $[109,112]$. A preliminary clinical trial demonstrated the potential for the subcutaneous injection of NT-3 in patients with CMT1A, a PNS neuropathy caused by a mutation in the gene-encoding peripheral myelin protein in Schwann cells [113]. Although these data indicate the therapeutic use of NT-3, larger cohort studies are needed before it can be applied to TBI.

\subsection{Neurotrophin $4 / 5$}

NT-4 is a member of the neurotrophin family that regulates the survival, differentiation, and regeneration of mammalian neurons. It is also known as NT-5 [114-116]. NT-4/5, the least understood neurotrophin, is the most widely distributed neurotrophin that exists universally in embryonic and adult rat tissues and appears to be less affected by environmental signals in surrounding regions in contrast to other neurotrophins [117]. 
NT- $4 / 5$ can relieve the neuroinflammation and enhance the neurological functioning in newborn rat models with germinal matrix hemorrhage (GMH) via the TrkB/PI3K/FoxO1 pathway and may be a potential treatment for neuroinflammation and hydrocephalus following GMH or other comparable brain lesions [118]. NT-4/5 might protect a cultured embryonic rat hippocampus and cortical neurons from glucose deprivation-induced damage as well as decrease neuronal vulnerability to glutamate toxicity $[119,120]$. Furthermore, neurons treated with NT- $4 / 5$ were more resistant to toxicity caused by calcium ion carriers, showing that NT- $4 / 5$ conferred neuronal resistance to calcium-mediated damage [119].

NT-4/5-deficient mice exhibited preferential pyramidal cell loss in the CA of the hippocampus following TBI as well as a prolonged recovery period of motor function compared with their brain-injured controls [60]. The loss of pyramidal cells in CA could be restored with early and sustained infusions of recombinant NT-4/5, but not with functional impairment [121], indicating that NT-4/5 may serve as an adaptive neuroprotective response in the damaged neuronal network [60]. Endogenous NT-4/5 expression and release, which were shown to be upregulated following TBI, are modulated by CNS disorders such as TBI $[59,60]$, particularly in the damaged cortex and hippocampus in the acute phase (3 days) [60]. In addition, NT-4/5 secreted at inflammation sites is thought to be useful in tissue regeneration and shows potential as a future treatment option after TBI $[60,121]$. As a result, NT- $4 / 5$ plays a key role in brain development and has the capacity to recapitulate numerous processes involved in brain growth as well as providing neuroprotection for susceptible neurons [58].

\section{Potential Therapeutic Role of Neurotrophins in TBI}

\subsection{Diet}

Several studies have emphasized the vital role of nutrition in influencing TBI prognosis and recommended various beneficial diets to the patients with TBI via regulating neurotrophins and/or their receptors, including procyanidins [122], vitamin E supplements [123], blueberry [124], docosahexaenoic acid (DHA) supplement [125], omega-3 fatty acids [126,127], ethanol intoxication [128], curcumin [129], chronic caloric restriction [130], astaxanthin [131], DL-3-n-butylphthalide (NBP) [132], cysteine-rich whey protein supplement (Immunocal ${ }^{\circledR}$ ) [133], resolvin D1 (RvD1) [134], and trehalose [135]. Conversely, there is still a dietary category that aggravates the impairment in TBI patients, including high-saturated-fat diets [123].

Procyanidins, with a potent antioxidant activity, were hypothesized to engage in TBI neuroprotection by lowering malondialdehyde levels and increasing glutathione (GSH) and SOD levels. Furthermore, procyanidins increased the BDNF, cyclic AMP (cAMP), and cAMP response element binding protein (CREB) levels, which resulted in a better cognitive performance in the Morris water maze [122].

In a rat model of fluid percussion injury, vitamin E supplementation can protect against cognitive impairment after TBI by engaging in BDNF-mediated synaptic plasticity, that is, synapsin I, CREB, and calcium/calmodulin-dependent protein kinase II [136].

Blueberry consumption shortly after TBI reduces behavioral impairment and neural dysfunction. Blueberry food supplementation improves spatial and object recognition memory and increases BDNF-mediated plasticity in a rat model of fluid percussion injury [124]. Furthermore, a human study revealed that the consumption of coffee berries also induced increased levels of plasma BDNF by $143 \%$, compared with baseline. Therefore, coffee berries might have a BDNF-dependent effect in TBI. However, there is no study directly clarifying the effects of coffee berries in TBI [137].

DHA in the diet may protect against learning impairment after TBI by increasing BDNF-mediated plasticity in a fluid percussion injury rat model [125].

Sufficient dietary omega-3 fatty acid supplementation was associated with increased levels of BDNF, TrkB receptor, and CREB expression in the lumbar spinal cord and acquired resistance to energy homeostasis changes and mitochondrial metabolic imbalance in a rat model of fluid percussion injury [126,127]. 
Ethanol can only reverse the injury-induced responses and downregulate the regulatory expression of the BDNF gene merely in moderate TBI with ethanol pre-TBI treatment in a closed weight-drop TBI mouse model [128].

Curcumin is an effective free radical scavenger [138]. Wu et al. demonstrated that consuming the antioxidant curcumin can decrease the negative effects of TBI on synaptic plasticity and cognition by restoring altered levels of BDNF, synapsin I, and CREB following TBI in a mild fluid percussion injury rat model of TBI [129].

In a controlled cortical impact rat model, chronic calorie restriction reduced the extent of the cortical lesion after damage, improved spatial memory, and increased BDNF levels in the cortical area surrounding the site of injury and in the hippocampus [130].

Compared with the vehicle-treated TBI group in the M.A. Flierl weight-drop mouse TBI model, an astaxanthin treatment through oral gavage improved the sensorimotor performance, improved the cognitive function recovery and reduced the lesion size and neuronal death in the cortex. Astaxanthin also restored the levels of BDNF, growth-associated protein 43 , synapsin, and synaptophysin in the cerebral cortex, indicating that it promotes neuronal survival and plasticity [131].

NBP therapy enhanced the sensorimotor functional recovery and substantially decreased the post-TBI depressed behavior. A consecutive daily intranasal NBP administration enhanced neurogenesis, angiogenesis, and arteriogenesis in the post-TBI brain in a controlled cortical impact mouse model, followed by the upregulations of BDNF, VEGF, endothelial-derived nitric oxide synthase (eNOS), and matrix metallopeptidase 9 (MMP-9) [132].

Immunocal ${ }^{\circledR}$ is a non-denatured whey protein product that has been demonstrated to work as a cysteine delivery method to enhance GSH levels [139]. In the controlled cortical impact mouse TBI model, there was a significant preservation of axonal myelination, a significant decrease in degenerating neurons, a reduction in Iba1 (microglial marker), and a preservation of BDNF in the brains of Immunocal ${ }^{\circledR}$-pretreated mice compared with untreated TBI mice, indicating that Immunocal ${ }^{\circledR}$ supplementation before TBI significantly improves the resilience to TBI [133].

In a controlled cortical impact mouse TBI model, RvD1 was found to enhance the expression of glutamate aspartate transporter and BDNF in the hippocampus. By regulating neuroinflammation and preserving astrocytic mitochondria, RvD1 may be a promising treatment approach for reversing cognitive impairment after TBI [134].

In a controlled cortical impact injury mouse TBI model, trehalose therapy resulted in a substantial increase in BDNF and pro-BDNF expression in the contralateral cortex, correlating with both synaptophysin and doublecortin protein expression levels in the same area. These findings suggest that trehalose has a neuroprotective effect in TBI and may also play a role in post-injury synaptic reorganization [135].

\subsection{Exercise}

Apart from diet, exercise also has beneficial but selective effects on the human cognitive function, especially in older adults $[140,141]$. The application of both physical activity and diet have variable effects [142]. Among all the effects published, BDNF seemed to be involved in the mechanism of exercise-associated regulation; hence, exercise was thought to be the potential factor for neural recovery in patients with TBI $[143,144]$.

In all of the TBI animal models studied, nine studies found that exercise increased BDNF levels and/or BDNF mRNA expression, showing that the activation of BDNF-TrkB receptors is crucial in the mechanism of exercise-modulated effects [145-153]. However, one study found that exercise regimens with significant stress reactions may not be helpful during the early post-injury phase, resulting in elevated BDNF levels in exercise-treated fluid percussion injury rat TBI models [154].

Interestingly, five studies followed the previous ones and tried to modulate some of the parameters in experiments such as voluntary or forced exercise, the onset time of exercise, and the intensity of exercises. These three parameters all modulated some 
of the variables to determine whether the dependent effects of exercise on TBI-induced impairments existed. One study showed that forced exercise led to decreased BDNF levels, whereas voluntary exercise increased the BDNF levels. Since forced physical training was seen as a stressor that elevated the corticosterone levels [154], it seemed that strong stressors would retard the repair and recovery from TBI destruction [155]. The intensity of exercise was also the focus. The results demonstrated that a low-intensity exercise after TBI is effective in accelerating the recovery of TBI and upregulating the BDNF levels rather than a high-intensity exercise [156]. The onset time of exercise significantly affects the outcome of animals with TBI. Chen et al. demonstrated in a closed-head-injury mice model that an early exercise protocol ( 2 days post-injury) drastically increased the ability of recognition and memory, extensively protected the neurons from death, and promoted neurite regeneration compared with the late exercise protocol ( 9 days post-injury) [157]. In contrast, a further restoration of BDNF reduction induced by TBI was presented on the group with late exercises. This indicated that the restoration of BDNF would be disrupted in the closed-head-injury mouse model if the exercise intervention was administered too early [157]. Deductively, different severities of TBI need to match different onset times of exercise to produce maximal therapeutic effects [158].

Exercise benefits animals with TBI not only post-traumatically but also pre-traumatically. Studies of preventive exercise before TBI events showed increased BDNF concentrations, enhanced sensorimotor performance and cognitive functions, and decreased lesion volume in animals with exercise training before TBI [152,153].

\subsection{Stem Cell Therapy}

Because exogenous neurotrophins have difficulties crossing the BBB, innovative treatments such as mesenchymal stem cells, which have the unique ability to self-renew and differentiate into several lineages, have been proposed [159] (Table 2). According to previous studies, neural mesenchymal stem cells differentiate into new neurons as well as neuroglia and further modulate the production of neurotrophins in specific regions as well as the reaction of neural stem/stromal cells in response to CNS-related diseases or injuries, including TBI $[160,161]$. Nevertheless, there are still limitations such as the precise modulation of differentiation, ethical problems regarding the sources of stem cells, graft-versus-host diseases, and the safety and effectiveness of stem cell therapy [162].

Table 2. Potential therapeutic roles of neurotrophins in stem cell therapy for TBI.

\begin{tabular}{|c|c|c|c|c|c|c|}
\hline Stem Cell Type & Stem Cell Source & Model & $\begin{array}{c}\text { Key } \\
\text { Neurotrophin }\end{array}$ & Route & Description & Reference \\
\hline BMSC & SD rat & SD rat & NGF, BDNF & $\begin{array}{l}\text { Injured brain site } \\
\text { transplant }\end{array}$ & $\begin{array}{l}\text { TBI healing can be aided } \\
\text { by BMSCs with } \\
\text { SDF-1-induced CXCR4 } \\
\text { expression. }\end{array}$ & [163] \\
\hline BMSC & Wistar rat & Wistar rat & NGF, BDNF & Intravenous & $\begin{array}{l}\text { BMSCs contribute to the } \\
\text { improvement of the } \\
\text { functional outcome of TBI } \\
\text { rats. }\end{array}$ & {$[164]$} \\
\hline BMSC & SD rat & SD rat & BDNF & Intravenous & $\begin{array}{l}\text { BMSCs significantly } \\
\text { reduce TBI-induced } \\
\text { neuromotor impairment } \\
\text { and neuronal loss. }\end{array}$ & {$[165]$} \\
\hline BMSC & Wistar rat & Wistar rat & NGF, BDNF & Intravenous & $\begin{array}{l}\text { BMSC treatment } \\
\text { promotes functional } \\
\text { recovery. BMSCs induce } \\
\text { growth factor production. }\end{array}$ & [166] \\
\hline BMSC & SD rat & Mice & NT-3, NT-3 ${ }^{\text {P75-2 }}$ & $\begin{array}{l}\text { Injured brain site } \\
\text { transplant }\end{array}$ & $\begin{array}{c}\text { In a mouse TBI model, } \\
N T-3^{P 75}-2 \text {-gene-modified } \\
\text { bone mesenchymal stem } \\
\text { cells enhance neurological } \\
\text { function recovery. }\end{array}$ & [167] \\
\hline
\end{tabular}


Table 2. Cont.

\begin{tabular}{|c|c|c|c|c|c|c|}
\hline Stem Cell Type & Stem Cell Source & Model & $\begin{array}{c}\text { Key } \\
\text { Neurotrophin }\end{array}$ & Route & Description & Reference \\
\hline hUC-MSCs & $\begin{array}{l}\text { WJ tissue from } \\
\text { hUC }\end{array}$ & SD rat & BDNF & $\begin{array}{l}\text { Injured brain site } \\
\text { transplant }\end{array}$ & $\begin{array}{l}\text { In a rat model of TBI, } \mathrm{WJ} \\
\text { transplantation improves } \\
\text { brain function. }\end{array}$ & [168] \\
\hline hMSC & Human & SD rat & NGF, BDNF, NT-3 & $\begin{array}{l}\text { Injured brain site } \\
\text { transplant }\end{array}$ & $\begin{array}{l}\text { TBI treated with hMSCs } \\
\text { in the acute period can } \\
\text { improve neurological the } \\
\text { functional outcome. }\end{array}$ & [169] \\
\hline MSC & Rat & SD rat & BDNF & Intravenous & $\begin{array}{l}\text { After TBI, BDNF-induced } \\
\text { MSCs-Exo may } \\
\text { successfully enhance } \\
\text { functional recovery and } \\
\text { neurogenesis in rats. }\end{array}$ & [170] \\
\hline MSC & Wistar rat & Wistar rat & NGF, BDNF & $\begin{array}{l}\text { Injured brain site } \\
\text { transplant }\end{array}$ & $\begin{array}{l}\text { There are differences in } \\
\text { neurotrophin expression, } \\
\text { although they are not } \\
\text { statistically significant. }\end{array}$ & [171] \\
\hline hMSC & Human & SD rat & BDNF & Intravenous & $\begin{array}{c}\text { Reducing } \\
\text { proinflammatory cytokine } \\
\text { expression in the brain } \\
\text { tissues after TBI and } \\
\text { before hMSC therapy } \\
\text { enhances the success of } \\
\text { the therapy, in which } \\
\text { BDNF may have a role. }\end{array}$ & [172] \\
\hline NSC & $\begin{array}{c}\mathrm{GFP}+\mathrm{C} 57 \mathrm{BL} / 6 \\
\text { mice }\end{array}$ & SD rat & BDNF & $\begin{array}{l}\text { Injured brain site } \\
\text { transplant }\end{array}$ & $\begin{array}{l}\text { TBI functional recovery is } \\
\text { aided by NSC } \\
\text { transplantation via } \\
\text { BDNF-mediated } \\
\text { neuroplasticity. }\end{array}$ & [173] \\
\hline AMSC, AM-NSC & Human & SD rat & NGF, BDNF, NT-3 & $\begin{array}{l}\text { Injured brain site } \\
\text { transplant }\end{array}$ & $\begin{array}{l}\text { TBI in rats can be } \\
\text { effectively treated using } \\
\text { neural stem-like cells } \\
\text { generated from human } \\
\text { amnion tissue. }\end{array}$ & [174] \\
\hline $\begin{array}{l}\text { Differentiation } \\
\text { ESC }\end{array}$ & Mouse ES cell line & $\begin{array}{l}\text { C57BL/6 } \\
\text { mice }\end{array}$ & NGF, BDNF & $\begin{array}{l}\text { Injured brain site } \\
\text { transplant }\end{array}$ & $\begin{array}{l}\text { The transplanted } \\
\text { neurospheres were able to } \\
\text { survive in the mild TBI } \\
\text { mice but not in the severe } \\
\text { TBI animals. }\end{array}$ & [175] \\
\hline NSC & Wistar rat & Wistar rat & BDNF & $\begin{array}{l}\text { Injured brain site } \\
\text { transplant }\end{array}$ & $\begin{array}{l}\text { The protective impact of } \\
\text { BDNF-modified NSCs } \\
\text { transplantation } \\
\text { outperforms that of naive } \\
\text { NSCs transplantation. }\end{array}$ & [176] \\
\hline NSC & Wistar rat & Wistar rat & BDNF & $\begin{array}{l}\text { Injured brain site } \\
\text { transplant }\end{array}$ & $\begin{array}{c}\text { Following NSC } \\
\text { transplantation, BDNF } \\
\text { enhances synaptic protein } \\
\text { levels via the MAPK/Erk } \\
\text { signaling pathway and } \\
\text { the Nrf2/Trx axis in a rat } \\
\text { model of TBI. }\end{array}$ & [177] \\
\hline UC-MSC & Human & SD rat & BDNF & $\begin{array}{l}\text { Injured brain site } \\
\text { transplant }\end{array}$ & $\begin{array}{l}\text { By inhibiting the release } \\
\text { of inflammatory factors } \\
\text { and increasing the } \\
\text { production of GDNF and } \\
\text { BDNF, UC-MSCs may } \\
\text { play an essential role in } \\
\text { TBI recovery. }\end{array}$ & [178] \\
\hline
\end{tabular}


Table 2. Cont.

\begin{tabular}{|c|c|c|c|c|c|c|}
\hline Stem Cell Type & Stem Cell Source & Model & $\begin{array}{c}\text { Key } \\
\text { Neurotrophin }\end{array}$ & Route & Description & Reference \\
\hline NSC, hUC-MSC & SD rat, human & SD rat & BDNF & $\begin{array}{l}\text { Injured brain site } \\
\text { transplant }\end{array}$ & $\begin{array}{l}\text { CGB scaffolds coated with } \\
\text { hUC-MSCs can have two } \\
\text { impacts for TBI treatment: } \\
\text { they can compensate for } \\
\text { neuron loss after TBI and } \\
\text { they can release active } \\
\text { BDNF from the scaffold, } \\
\text { leading NSCs in situ in } \\
\text { the brain to develop into } \\
\text { neurons. }\end{array}$ & [179] \\
\hline hUC-MSC & Human & SD rat & BDNF & $\begin{array}{l}\text { Injured brain site } \\
\text { transplant }\end{array}$ & $\begin{array}{l}\text { Transplantation of } \\
\text { UC-MSCs for the } \\
\text { treatment of acute TBI can } \\
\text { significantly decrease } \\
\text { damage and enhance } \\
\text { vascular repair. }\end{array}$ & [180] \\
\hline hUC-MSC & Human & $\begin{array}{l}\text { C57BL/6 } \\
\text { mice }\end{array}$ & NGF & Intravenous & $\begin{array}{l}\text { This work shows that } \\
\text { NGF-induced } \\
\text { anti-inflammatory and } \\
\text { immunomodulatory } \\
\text { characteristics of the } \\
\text { CD45+ subpopulation are } \\
\text { mediated via systemic IV } \\
\text { xenotransplantation into } \\
\text { TBI mice. }\end{array}$ & [181] \\
\hline HUCPVC & Human & SD rat & NGF, NT-3 & Intravenous & $\begin{array}{l}\text { This work demonstrates } \\
\text { the importance of } \\
\text { perivascular cells in } \\
\text { shielding axons from } \\
\text { damage and suggests a } \\
\text { possible cell-based } \\
\text { treatment to treat } \\
\text { secondary injury } \\
\text { after TBI. }\end{array}$ & [182] \\
\hline hUC-MSC & Human & SD rat & BDNF & $\begin{array}{l}\text { Injured brain site } \\
\text { transplant }\end{array}$ & $\begin{array}{l}\text { This study discovered that } \\
\text { the co-culture of } \\
\text { hUC-MSCs and activated } \\
\text { astrocytes increases BDNF } \\
\text { production, which may } \\
\text { enhance both ectogenic } \\
\text { hUC-MSC neural } \\
\text { development and } \\
\text { endogenic neurogenesis. }\end{array}$ & [183] \\
\hline
\end{tabular}

AM-NSC; AMSC; BDNF, brain-derived neurotrophic factor; BMSC, bone marrow stem cell; CGB, genipincrosslinked; CXCR4, CXC chemokine receptor 4; ES; ESC; GDNF, glial cell line-derived neurotrophic factor; hMSC, human mesenchymal stem cell; hUC, human umbilical cord; HUCPVC, human umbilical cord perivascular cells; MAPK, mitogen-activated protein kinase; MSC, mesenchymal stem cell; NGF, nerve growth factor; Nrf2, nuclear factor erythroid 2-related factor 2; NSC, neural stem cell; NT-3, neurotrophin 3; SD, Sprague-Dawley; SDF-1, stromal cell-derived factor 1; TBI, traumatic brain injury; Trx, thioredoxin-1; UC-MSC, umbilical cord mesenchymal stem cell; WJ, Wharton's jelly.

\subsubsection{Bone Marrow Stem Cells}

Studies on rat TBI models treated with bone marrow stem cells (BMSCs) in response to TBI have yielded substantial positive results [164]. Rat TBI models administered with BMSCs generally presented better neurological outcomes with improved cognitive functions, behavioral performance, and shorter latency to reaction in the tests [165]. The neuronal loss and impairment induced by TBI were decreased, whereas the transplantation of these cells migrated into or around the injured areas, where more differentiated neurons and astrocytes were observed immunologically [163]. In terms of neurotrophins, increased NGF [163,164] and BDNF [163-166] expression was found in the CNS of the animals, whereas the decreased expression of the BCL2-associated agonist of cell death and BCL2-associated X 
protein signaling and increased synaptophysin explained the possible mechanism involved in the stem cell therapy process. A study on NT-3 $3^{P 75-2}$ gene-modified BMSCs, which overexpress NT-3 proteins, also showed satisfactory outcomes in vitro and in vivo following TBI [167].

\subsubsection{Human Mesenchymal Stem Cells}

Animals treated with human mesenchymal stem cells (hMSCs) following TBI showed an improved neurological function, cognitive capacity, and memory capacity, decreased volume of lesion areas, and attenuated brain edema. hMSCs are applied along with Wharton's jelly, which is primarily composed of mucopolysaccharides and a matrix from which hMSC s can be extracted [168-170]. BDNF, NGF, and NT-3 were significantly elevated at 2 days post-injury [169], whereas in another study the increase in BDNF mRNA expression was also found at 14 days post-injury [168]. The results of a western blot analysis of up-regulated Akt expression and decreased caspase 3 cleavage after TBI also presented a possible mechanism underlying hMSCs therapy in TBI [169]. However, evidence-based effective methods of delivery, such as intraperitoneal administration [168], are also critical for efficiently correcting TBI damage, since the subarachnoid injection of hMSCs in TBI rats exhibited no significant changes in their neurological performance and neurotrophin expression [171]. Bonilla discovered that subarachnoid-transplanted cells were localized near the injection site. Some were identified at the site of the lesion, but no mesenchymal stem cells were detected in the healthy brain tissue. This might be the reason why the subarachnoid injection caused no significant difference [171]. When combined with pioglitazone, which reduces the pro-inflammatory chemokines, the hMSCs further showed enhanced sensorimotor responses and increased BDNF expression [172].

\subsubsection{Neural Stem Cells}

Apart from the stem cells mentioned above, neural stem cells (NSCs) have shown neuroprotective properties in response to TBI [173]. Mice injected with NSCs after TBI showed improved spatial and memory functions in addition to the enhanced neurological functions [174]. Morphologically, the NSCs successfully survived in the hippocampus of transplanted rats, especially in the CA1 region [184], and largely differentiated into neurons with anti-inflammatory functions with surrounding astrocytes. In terms of neurotrophins and neurotrophic factors, NSC treatment enhanced the expression of NGF, BDNF, NT-3, GDNF, cerebral dopamine neurotrophic factor [174], and synaptophysin [173]. The mechanism underlying the phenomenon might lie in the decreased expression of glutamic acid and $\alpha$-smooth muscle actin [185] and the maintained level of $\gamma$-aminobutyric acid, indicating the downregulated excitotoxicity of neurotransmitters [184]. However, the intensity of trauma is still important because the up-regulation of neurotrophins in NSC treatment was significant only in the condition of mild TBI instead of severe TBI [175]. The gene-modified NSCs overexpressing BDNF showed a better rate of survival and differentiation $[176,177]$. Nevertheless, an artificial gene-modified NSC overexpressing multineurotrophin (MNTS1), a neurotrophin binding and activating all three types of Trk receptors, showed no significant improvement in the cytoarchitecture and behavioral ability compared with the non-genetically modified NCS-treated mice, indicating the superfluous augmentation of NSC-MNTS1 [186].

\subsubsection{Human Umbilical Cord Mesenchymal Stem Cells}

Another subpopulation known as human umbilical cord mesenchymal stem cells (hUC-MSCs) was also tested for its potential usage in the treatment of TBI. Irrespective of whether umbilical cords were derived from neonatal rats [178], contained in chitosan scaffolds [179], or extracted from a human umbilical cord-matrix [180], the animals given hUC-MSCs showed better neurological severity scores and alleviated brain edema after TBI compared to the mice without stem cell treatment. Morphologically, the promotion of neural regeneration, improved rates of differentiation, and inhibition of inflammatory 
cells have also been well demonstrated. The expressions of BDNF, GDNF [178], glial fibrillary acidic protein, and microvessel density were significantly upregulated in the CNS of hUC-MSCs-treated mice [180]. NGF and associated TrkA receptors as well as p75 ${ }^{\text {NTR }}$ were also highly expressed in similar studies that treated mice with human umbilical cord blood CD45 ${ }^{+}$cell cultures [181]. Perivascular cells form a human umbilical cord have been shown to prevent axonal degeneration in response to NGF withdrawal or oxygen glucose deprivation in vitro [182]. Furthermore, a co-culture of hUC-MSCs and activated astrocytes as well as forcing hUC-MSCs with CXC chemokine receptor 4 [183], which may stimulate stem cell migration, improved the differentiation and repair capacities in the brain parenchyma.

\section{Energy Balance Regulation by Neurotrophins in TBI}

According to the metabolite availability, the brain is an energy-intensive organ that may use glucose or ketone bodies as energy sources [187]. The rise in glutamate levels in TBI commences a few minutes after the initial trauma, peaks in approximately 10 minutes, and lasts for many days [188]. The elevated release of glutamate into the extracellular milieu following injury is a pivotal event that causes metabolic dysfunction, generating significant increases in cerebral glucose utilization and extracellular lactate production [189-193]. Mitochondrial dysfunction is another significant event associated with the post-TBI energy crisis, since the increased energetic demand cannot be satisfied [194] Furthermore, following TBI, the glucose metabolism is changed, which is attributed in part to oxygen deprivation [195]. After TBI, there is a rise in the Lactate/Pyruvate ratio, indicating a shift toward anaerobic metabolism in both animal models [196,197] and human beings [198]. The deregulation of the brain's metabolism results in a decrease in cerebral energy generation. Reduced ATP levels then induce the failure of ATP-dependent ion channels and proteins, resulting in ionic osmotic changes that cause cell swelling and eventually cell death [199]. As a result, the restoration of injured nervous tissue necessitates more energy than the tissue's normal physiological condition [200].

Some studies indicate that BDNF signaling in the brain mediates the beneficial impacts of a cognitively and physically demanding environment on energy metabolism, such as enhanced insulin sensitivity [201], increased brown fat genesis [202,203], and cardiovascular fitness [204]. Inhibiting BDNF/TrkB signaling in the periphery resulted in the downregulation of numerous metabolic factors, including AMP-activated protein kinase (AMPK), a protein kinase associated with cell energy regulation homeostasis [205]. BDNF may give a survival advantage to individuals experiencing nervous system damage by boosting mitochondrial biogenesis and increasing neuronal resilience to injury by up-regulating the expression of genes encoding cytoprotective proteins [206].

Several neurotrophins have emerged as key participants in the complicated systems that control food intake and energy expenditure as well as in potential disease processes that contribute to obesity [207]. The molecular and cellular foundations of the neurotrophin function affecting the energy balance and cerebral metabolism in TBI are crucial research topics that need to be explored further [187].

\section{Conclusions}

Neurotrophins play important roles in many aspects of neural development, survival, and plasticity. Many studies have focused on the response of neurotrophins during TBI. Some possible therapeutic effects of neurotrophins in TBI have also been demonstrated. By summarizing these studies, we hope to provide some insights for further research in the field of neurotrophins and TBI.

Author Contributions: Conceptualization, L.-T.K.; investigation, P.-H.L., L.-T.K.; writing-original draft preparation, P.-H.L.; writing-review and editing, L.-T.K., H.-T.L.; supervision, L.-T.K., H.-T.L. All authors have read and agreed to the published version of the manuscript.

Funding: This research received no external funding. 


\section{Institutional Review Board Statement: Not applicable.}

Informed Consent Statement: Not applicable.

Data Availability Statement: Not applicable.

Conflicts of Interest: The authors declare no conflict of interest.

\section{References}

1. Bradshaw, R.A.; Blundell, T.L.; Lapatto, R.; McDonald, N.Q.; Murray-Rust, J. Nerve growth factor revisited. Trends Biochem. Sci. 1993, 18, 48-52. [CrossRef]

2. Heymach, J.V., Jr.; Shooter, E.M. Biosynthesis of neurotrophin heterodimers in transfected mammalian cells. J. Biol. Chem. 1995, 270, 12297-12304. [CrossRef] [PubMed]

3. Levi-Montalcini, R. Nerve growth factor 35 years later. Science 1987, 237, 1154-1162. [CrossRef] [PubMed]

4. Keefe, K.M.; Sheikh, I.S.; Smith, G.M. Targeting neurotrophins to specific populations of neurons: NGF, BDNF, and NT-3 and their relevance for treatment of spinal cord injury. Int. J. Mol. Sci. 2017, 18, 548. [CrossRef] [PubMed]

5. Mattson, M.P.; Scheff, S.W. Endogenous neuroprotection factors and traumatic brain injury: Mechanisms of action and implications for therapy. J. Neurotrauma 1994, 11, 3-33. [CrossRef]

6. Reichardt, L.F. Neurotrophin-regulated signaling pathways. Philos. Trans. R. Soc. Lond. B Biol. Sci. 2006, 361, 1545-1564. [CrossRef]

7. Lee, R.; Kermani, P.; Teng, K.K.; Hempstead, B.L. Regulation of cell survival by secreted proneurotrophins. Science 2001, 294, 1945-1948. [CrossRef]

8. Chao, M.V. Neurotrophins and their receptors: A convergence point for many signaling pathways. Nat. Rev. Neurosci. 2003, 4 , 299-309. [CrossRef]

9. Huang, E.J.; Reichardt, L.F. Neurotrophins: Roles in neuronal development and function. Annu. Rev. Neurosci. 2001, 24, 677-736. [CrossRef]

10. Ultsch, M.H.; Wiesmann, C.; Simmons, L.C.; Henrich, J.; Yang, M.; Reilly, D.; Bass, S.H.; de Vos, A.M. Crystal structures of the neurotrophin-binding domain of TrkA, TrkB, and TrkC. J. Mol. Biol. 1999, 290, 149-159. [CrossRef]

11. Klein, R.; Nanduri, V.; Jing, S.A.; Lamballe, F.; Tapley, P.; Bryant, S.; Cordon-Cardo, C.; Jones, K.R.; Reichardt, L.F.; Barbacid, M. The trkB tyrosine protein kinase is a receptor for brain-derived neurotrophic factor and neurotrophin-3. Cell 1991, 66, 395-403. [CrossRef]

12. Snider, W.D. Functions of the neurotrophins during nervous system development: What the knockouts are teaching us. Cell 1994, 77, 627-638. [CrossRef]

13. Verdi, J.M.; Birren, S.J.; Ibanez, C.F.; Persson, H.; Kaplan, D.R.; Benedetti, M.; Chao, M.V.; Anderson, D.J. p75LNGFR regulates Trk signal transduction and NGF-induced neuronal differentiation in MAH cells. Neuron 1994, 12, 733-745. [CrossRef]

14. Ip, N.Y.; Stitt, T.N.; Tapley, P.; Klein, R.; Glass, D.J.; Fandl, J.; Greene, L.A.; Barbacid, M.; Yancopoulos, G.D. Similarities and differences in the way neurotrophins interact with the Trk receptors in neuronal and non-neuronal cells. Neuron 1993, 10, 137-149. [CrossRef]

15. Bibel, M.; Hoppe, E.; Barde, Y.A. Biochemical and functional interactions between the neurotrophin receptors Trk and p75NTR. EMBO J. 1999, 18, 616-622. [CrossRef] [PubMed]

16. Hempstead, B.L.; Martin-Zanca, D.; Kaplan, D.R.; Parada, L.F.; Chao, M.V. High-affinity NGF binding requires co-expression of the trk proto-oncogene and the low-affinity NGF receptor. Nature 1991, 350, 678-683. [CrossRef]

17. Benedetti, M.; Levi, A.; Chao, M.V. Differential expression of nerve growth factor receptors leads to altered binding affinity and neurotrophin responsiveness. Proc. Natl. Acad. Sci. USA 1993, 90, 7859-7863. [CrossRef]

18. Barbacid, M. The Trk family of neurotrophin receptors. J. Neurobiol. 1994, 25, 1386-1403. [CrossRef] [PubMed]

19. Kaplan, D.R.; Miller, F.D. Neurotrophin signal transduction in the nervous system. Curr. Opin. Neurobiol. 2000, 10, 381-391. [CrossRef]

20. Schlessinger, J. Cell signaling by receptor tyrosine kinases. Cell 2000, 103, 211-225. [CrossRef]

21. Blum, R.; Konnerth, A. Neurotrophin-mediated rapid signaling in the central nervous system: Mechanisms and functions. Physiology 2005, 20, 70-78. [CrossRef]

22. Zeng, F.; Lu, J.J.; Zhou, X.F.; Wang, Y.J. Roles of p75NTR in the pathogenesis of Alzheimer's disease: A novel therapeutic target. Biochem. Pharm. 2011, 82, 1500-1509. [CrossRef] [PubMed]

23. Hempstead, B.L. Dissecting the diverse actions of pro- and mature neurotrophins. Curr. Alzheimer Res. 2006, 3, 19-24. [CrossRef] [PubMed]

24. Kraemer, B.R.; Yoon, S.O.; Carter, B.D. Biological functions and signaling mechanisms of the p75 neurotrophin receptor. Handb. Exp. Pharm. 2014, 220, 121-164. [CrossRef]

25. Seidah, N.G.; Benjannet, S.; Pareek, S.; Chretien, M.; Murphy, R.A. Cellular processing of the neurotrophin precursors of NT3 and BDNF by the mammalian proprotein convertases. FEBS Lett. 1996, 379, 247-250. [CrossRef] 
26. Seidah, N.G.; Benjannet, S.; Pareek, S.; Savaria, D.; Hamelin, J.; Goulet, B.; Laliberte, J.; Lazure, C.; Chretien, M.; Murphy, R.A. Cellular processing of the nerve growth factor precursor by the mammalian pro-protein convertases. Biochem. J. 1996, 314, 951-960. [CrossRef]

27. Masoudi, R.; Ioannou, M.S.; Coughlin, M.D.; Pagadala, P.; Neet, K.E.; Clewes, O.; Allen, S.J.; Dawbarn, D.; Fahnestock, M. Biological activity of nerve growth factor precursor is dependent upon the relative levels of its receptors. J. Biol. Chem. 2009, 284, 18424-18433. [CrossRef]

28. Makkerh, J.P.; Ceni, C.; Auld, D.S.; Vaillancourt, F.; Dorval, G.; Barker, P.A. p75 neurotrophin receptor reduces ligand-induced Trk receptor ubiquitination and delays Trk receptor internalization and degradation. EMBO Rep. 2005, 6, 936-941. [CrossRef]

29. Geetha, T.; Jiang, J.; Wooten, M.W. Lysine 63 polyubiquitination of the nerve growth factor receptor TrkA directs internalization and signaling. Mol. Cell 2005, 20, 301-312. [CrossRef]

30. Roux, P.P.; Bhakar, A.L.; Kennedy, T.E.; Barker, P.A. The p75 neurotrophin receptor activates Akt (protein kinase B) through a phosphatidylinositol 3-kinase-dependent pathway. J. Biol. Chem. 2001, 276, 23097-23104. [CrossRef]

31. Kernie, S.G.; Parent, J.M. Forebrain neurogenesis after focal ischemic and traumatic brain injury. Neurobiol. Dis. 2010, 37, 267-274. [CrossRef]

32. Schoch, K.M.; Madathil, S.K.; Saatman, K.E. Genetic manipulation of cell death and neuroplasticity pathways in traumatic brain injury. Neurotherapeutics 2012, 9, 323-337. [CrossRef]

33. Stein, D.G.; Hoffman, S.W. Concepts of CNS plasticity in the context of brain damage and repair. J. Head Trauma Rehabil. 2003, 18, 317-341. [CrossRef]

34. Yu, T.S.; Zhang, G.; Liebl, D.J.; Kernie, S.G. Traumatic brain injury-induced hippocampal neurogenesis requires activation of early nestin-expressing progenitors. J. Neurosci. 2008, 28, 12901-12912. [CrossRef]

35. Chiaretti, A.; Antonelli, A.; Genovese, O.; Pezzotti, P.; Rocco, C.D.; Viola, L.; Riccardi, R. Nerve growth factor and doublecortin expression correlates with improved outcome in children with severe traumatic brain injury. J. Trauma 2008, 65, 80-85. [CrossRef] [PubMed]

36. Walter, H.J.; Berry, M.; Hill, D.J.; Cwyfan-Hughes, S.; Holly, J.M.; Logan, A. Distinct sites of insulin-like growth factor (IGF)-II expression and localization in lesioned rat brain: Possible roles of IGF binding proteins (IGFBPs) in the mediation of IGF-II activity. Endocrinology 1999, 140, 520-532. [CrossRef]

37. Kozlowski, G.P. Hormone pathways in cerebrospinal fluid. Neurol. Clin. 1986, 4, 907-917. [CrossRef]

38. Scott, D.E.; Krobisch-Dudley, G.; Paull, W.K.; Kozlowski, G.P. Ventricular system in neuroendocrine mechanisms III. Supraependymal neuronal networks in primate brain. Cell Tissue Res. 1977, 179, 235-254. [CrossRef]

39. Sharma, H.S.; Johanson, C.E. Intracerebroventricularly administered neurotrophins attenuate blood cerebrospinal fluid barrier breakdown and brain pathology following whole-body hyperthermia: An experimental study in the rat using biochemical and morphological approaches. Ann. N. Y. Acad. Sci. 2007, 1122, 112-129. [CrossRef]

40. Skinner, S.J.; Geaney, M.S.; Rush, R.; Rogers, M.L.; Emerich, D.F.; Thanos, C.G.; Vasconcellos, A.V.; Tan, P.L.; Elliott, R.B. Choroid plexus transplants in the treatment of brain diseases. Xenotransplantation 2006, 13, 284-288. [CrossRef] [PubMed]

41. Knuckey, N.W.; Finch, P.; Palm, D.E.; Primiano, M.J.; Johanson, C.E.; Flanders, K.C.; Thompson, N.L. Differential neuronal and astrocytic expression of transforming growth factor beta isoforms in rat hippocampus following transient forebrain ischemia. Brain Res. Mol. Brain Res. 1996, 40,1-14. [CrossRef]

42. Lee, C.; Agoston, D.V. Vascular endothelial growth factor is involved in mediating increased de novo hippocampal neurogenesis in response to traumatic brain injury. J. Neurotrauma 2010, 27, 541-553. [CrossRef] [PubMed]

43. Sharma, H.S.; Johanson, C.E. Blood-cerebrospin al fluid barrier in hyperthermia. Prog. Brain Res. 2007, 162, 459-478. [CrossRef] [PubMed]

44. Kim, B.T.; Rao, V.L.; Sailor, K.A.; Bowen, K.K.; Dempsey, R.J. Protective effects of glial cell line-derived neurotrophic factor on hippocampal neurons after traumatic brain injury in rats. J. Neurosurg. 2001, 95, 674-679. [CrossRef] [PubMed]

45. Stumm, R.; Kolodziej, A.; Prinz, V.; Endres, M.; Wu, D.F.; Hollt, V. Pituitary adenylate cyclase-activating polypeptide is upregulated in cortical pyramidal cells after focal ischemia and protects neurons from mild hypoxic/ischemic damage. $J$. Neurochem. 2007, 103, 1666-1681. [CrossRef] [PubMed]

46. Nakamachi, T.; Ohtaki, H.; Yofu, S.; Dohi, K.; Watanabe, J.; Mori, H.; Sato, A.; Hashimoto, H.; Shintani, N.; Baba, A.; et al. Endogenous pituitary adenylate cyclase-activating polypeptide is involved in the suppression of edema in the ischemic brain. Acta Neurochir. Suppl. 2010, 106, 43-46. [CrossRef] [PubMed]

47. Bukovics, P.; Czeiter, E.; Amrein, K.; Kovacs, N.; Pal, J.; Tamas, A.; Bagoly, T.; Helyes, Z.; Buki, A.; Reglodi, D. Changes in PACAP levels in cerebrospinal fluid and plasma of patients with severe traumatic brain injury. Peptides 2014, 60, 18-22. [CrossRef] [PubMed]

48. Tamas, A.; Zsombok, A.; Farkas, O.; Reglodi, D.; Pal, J.; Buki, A.; Lengvari, I.; Povlishock, J.T.; Doczi, T. Postinjury administration of pituitary adenylate cyclase-activating polypeptide (PACAP) attenuates traumatically induced axonal injury in rats. J. Neurotrauma 2006, 23, 686-695. [CrossRef]

49. Kovesdi, E.; Tamas, A.; Reglodi, D.; Farkas, O.; Pal, J.; Toth, G.; Bukovics, P.; Doczi, T.; Buki, A. Posttraumatic administration of pituitary adenylate cyclase activating polypeptide in central fluid percussion injury in rats. Neurotox. Res. 2008, 13, 71-78. [CrossRef] 
50. Shioda, S.; Ohtaki, H.; Suzuki, R.; Nakamachi, T.; Takenoya, F.; Dohi, K.; Nakajo, S. Prevention of delayed neuronal cell death by PACAP and its molecular mechanism. Nihon Yakurigaku Zasshi 2004, 123, 243-252. [CrossRef]

51. Mao, S.S.; Hua, R.; Zhao, X.P.; Qin, X.; Sun, Z.Q.; Zhang, Y.; Wu, Y.Q.; Jia, M.X.; Cao, J.L.; Zhang, Y.M. Exogenous administration of PACAP alleviates traumatic brain injury in rats through a mechanism involving the TLR4/MyD88/NF-kappaB pathway. J. Neurotrauma 2012, 29, 1941-1959. [CrossRef]

52. Johanson, C.; Stopa, E.; Baird, A.; Sharma, H. Traumatic brain injury and recovery mechanisms: Peptide modulation of periventricular neurogenic regions by the choroid plexus-CSF nexus. J. Neural Transm. 2011, 118, 115-133. [CrossRef]

53. Skinner, S.J.; Geaney, M.S.; Lin, H.; Muzina, M.; Anal, A.K.; Elliott, R.B.; Tan, P.L. Encapsulated living choroid plexus cells: Potential long-term treatments for central nervous system disease and trauma. J. Neural Eng. 2009, 6, 065001. [CrossRef]

54. Pedraza, C.E.; Podlesniy, P.; Vidal, N.; Arevalo, J.C.; Lee, R.; Hempstead, B.; Ferrer, I.; Iglesias, M.; Espinet, C. Pro-NGF isolated from the human brain affected by Alzheimer's disease induces neuronal apoptosis mediated by p75NTR. Am. J. Pathol. 2005, 166, 533-543. [CrossRef]

55. Harrington, A.W.; Leiner, B.; Blechschmitt, C.; Arevalo, J.C.; Lee, R.; Morl, K.; Meyer, M.; Hempstead, B.L.; Yoon, S.O.; Giehl, K.M. Secreted proNGF is a pathophysiological death-inducing ligand after adult CNS injury. Proc. Natl. Acad. Sci. USA 2004, 101, 6226-6230. [CrossRef]

56. Fahnestock, M.; Michalski, B.; Xu, B.; Coughlin, M.D. The precursor pro-nerve growth factor is the predominant form of nerve growth factor in the brain and is increased in Alzheimer's disease. Mol. Cell Neurosci. 2001, 18, 210-220. [CrossRef] [PubMed]

57. Guan, J.; Bennet, L.; Gluckman, P.D.; Gunn, A.J. Insulin-like growth factor-1 and post-ischemic brain injury. Prog. Neurobiol. 2003, 70, 443-462. [CrossRef]

58. Madathil, S.K.; Saatman, K.E. IGF-1/IGF-R Signaling in Traumatic Brain Injury: Impact on Cell Survival, Neurogenesis, and Behavioral Outcome. In Brain Neurotrauma: Molecular, Neuropsychological, and Rehabilitation Aspects; Kobeissy, F.H., Ed.; CRC Press: Boca Raton, FL, USA, 2015; Chapter 7.

59. Madathil, S.K.; Evans, H.N.; Saatman, K.E. Temporal and regional changes in IGF-1/IGF-1R signaling in the mouse brain after traumatic brain injury. J. Neurotrauma 2010, 27, 95-107. [CrossRef]

60. Royo, N.C.; Conte, V.; Saatman, K.E.; Shimizu, S.; Belfield, C.M.; Soltesz, K.M.; Davis, J.E.; Fujimoto, S.T.; McIntosh, T.K. Hippocampal vulnerability following traumatic brain injury: A potential role for neurotrophin- $4 / 5$ in pyramidal cell neuroprotection. Eur. J. Neurosci. 2006, 23, 1089-1102. [CrossRef] [PubMed]

61. Chiaretti, A.; Antonelli, A.; Riccardi, R.; Genovese, O.; Pezzotti, P.; Di Rocco, C.; Tortorolo, L.; Piedimonte, G. Nerve growth factor expression correlates with severity and outcome of traumatic brain injury in children. Eur. J. Paediatr. Neurol. 2008, 12, 195-204. [CrossRef] [PubMed]

62. Munoz, M.J.; Kumar, R.G.; Oh, B.M.; Conley, Y.P.; Wang, Z.; Failla, M.D.; Wagner, A.K. Cerebrospinal fluid cortisol mediates brain-derived neurotrophic factor relationships to mortality after severe TBI: A prospective cohort study. Front. Mol. Neurosci. 2017, 10, 44. [CrossRef] [PubMed]

63. Longo, F.M.; Xie, Y.; Massa, S.M. Neurotrophin small molecule mimetics: Candidate therapeutic agents for neurological disorders. Curr. Med. Chem. 2005, 5, 13. [CrossRef]

64. Cantley, L.C. The phosphoinositide 3-kinase pathway. Science 2002, 296, 1655-1657. [CrossRef] [PubMed]

65. Agrawal, R.; Noble, E.; Tyagi, E.; Zhuang, Y.; Ying, Z.; Gomez-Pinilla, F. Flavonoid derivative 7,8-DHF attenuates TBI pathology via TrkB activation. Biochim. Biophys. Acta 2015, 1852, 862-872. [CrossRef] [PubMed]

66. Wu, C.H.; Hung, T.H.; Chen, C.C.; Ke, C.H.; Lee, C.Y.; Wang, P.Y.; Chen, S.F. Post-injury treatment with 7,8-dihydroxyflavone, a TrkB receptor agonist, protects against experimental traumatic brain injury via PI3K/Akt signaling. PLoS ONE 2014, 9, e113397. [CrossRef]

67. Wurzelmann, M.; Romeika, J.; Sun, D. Therapeutic potential of brain-derived neurotrophic factor (BDNF) and a small molecular mimics of BDNF for traumatic brain injury. Neural Regen. Res. 2017, 12, 7-12. [CrossRef]

68. DeKosky, S.T.; Taffe, K.M.; Abrahamson, E.E.; Dixon, C.E.; Kochanek, P.M.; Ikonomovic, M.D. Time course analysis of hippocampal nerve growth factor and antioxidant enzyme activity following lateral controlled cortical impact brain injury in the rat. $J$. Neurotrauma 2004, 21, 491-500. [CrossRef] [PubMed]

69. Hicks, R.R.; Martin, V.B.; Zhang, L.; Seroogy, K.B. Mild experimental brain injury differentially alters the expression of neurotrophin and neurotrophin receptor mRNAs in the hippocampus. Exp. Neurol. 1999, 160, 469-478. [CrossRef] [PubMed]

70. Yang, K.; Perez-Polo, J.R.; Mu, X.S.; Yan, H.Q.; Xue, J.J.; Iwamoto, Y.; Liu, S.J.; Dixon, C.E.; Hayes, R.L. Increased expression of brain-derived neurotrophic factor but not neurotrophin-3 mRNA in rat brain after cortical impact injury. J. Neurosci. Res. 1996, 44, 157-164. [CrossRef]

71. Rostami, E.; Krueger, F.; Plantman, S.; Davidsson, J.; Agoston, D.; Grafman, J.; Risling, M. Alteration in BDNF and its receptors, full-length and truncated TrkB and p75(NTR) following penetrating traumatic brain injury. Brain Res. 2014, 1542, $195-205$. [CrossRef]

72. Oyesiku, N.M.; Evans, C.O.; Houston, S.; Darrell, R.S.; Smith, J.S.; Fulop, Z.L.; Dixon, C.E.; Stein, D.G. Regional changes in the expression of neurotrophic factors and their receptors following acute traumatic brain injury in the adult rat brain. Brain Res. 1999, 833, 161-172. [CrossRef]

73. Merlio, J.P.; Ernfors, P.; Kokaia, Z.; Middlemas, D.S.; Bengzon, J.; Kokaia, M.; Smith, M.L.; Siesjo, B.K.; Hunter, T.; Lindvall, O.; et al Increased production of the TrkB protein tyrosine kinase receptor after brain insults. Neuron 1993, 10, 151-164. [CrossRef] 
74. Hicks, R.R.; Numan, S.; Dhillon, H.S.; Prasad, M.R.; Seroogy, K.B. Alterations in BDNF and NT-3 mRNAs in rat hippocampus after experimental brain trauma. Brain Res. Mol. Brain Res. 1997, 48, 401-406. [CrossRef]

75. Grundy, P.L.; Patel, N.; Harbuz, M.S.; Lightman, S.L.; Sharples, P.M. Adrenalectomy further suppresses the NT-3 mRNA response to traumatic brain injury; however, this effect is not reversed with corticosterone. Brain Res. Mol. Brain Res. 2004, 120, 188-192. [CrossRef]

76. Cuello, A.C. Effects of trophic factors on CNS cholinergic phenotype. Prog. Brain Res. 1996, 109, 347-358. [CrossRef] [PubMed]

77. Debeir, T.; Saragovi, H.U.; Cuello, A.C. A nerve growth factor mimetic TrkA antagonist causes withdrawal of cortical cholinergic boutons in adult rats. Proc. Natl. Acad. Sci. USA 1999, 96, 4067-4072. [CrossRef] [PubMed]

78. Sofroniew, M.V.; Howe, C.L.; Mobley, W.C. Nerve growth factor signaling, neuroprotection, and neural repair. Annu. Rev. Neurosci. 2001, 24, 1217-1281. [CrossRef]

79. Dixon, C.E.; Flinn, P.; Bao, J.; Venya, R.; Hayes, R.L. Nerve growth factor attenuates cholinergic deficits following traumatic brain injury in rats. Exp. Neurol. 1997, 146, 479-490. [CrossRef]

80. Laudiero, L.B.; Aloe, L.; Levi-Montalcini, R.; Buttinelli, C.; Schilter, D.; Gillessen, S.; Otten, U. Multiple sclerosis patients express increased levels of beta-nerve growth factor in cerebrospinal fluid. Neurosci. Lett. 1992, 147, 9-12. [CrossRef]

81. Aloe, L.; Tuveri, M.A.; Carcassi, U.; Levi-Montalcini, R. Nerve growth factor in the synovial fluid of patients with chronic arthritis. Arthritis Rheum. 1992, 35, 351-355. [CrossRef]

82. Barker, P.A.; Mantyh, P.; Arendt-Nielsen, L.; Viktrup, L.; Tive, L. Nerve growth factor signaling and its contribution to pain. J. Pain Res. 2020, 13, 1223-1241. [CrossRef] [PubMed]

83. Dai, W.L.; Yan, B.; Bao, Y.N.; Fan, J.F.; Liu, J.H. Suppression of peripheral NGF attenuates neuropathic pain induced by chronic constriction injury through the TAK1-MAPK/NF-kappaB signaling pathways. Cell Commun. Signal. 2020, 18, 66. [CrossRef] [PubMed]

84. Andero, R.; Choi, D.C.; Ressler, K.J. BDNF-TrkB receptor regulation of distributed adult neural plasticity, memory formation, and psychiatric disorders. Prog. Mol. Biol. Transl. Sci. 2014, 122, 169-192. [CrossRef] [PubMed]

85. Lima Giacobbo, B.; Doorduin, J.; Klein, H.C.; Dierckx, R.; Bromberg, E.; de Vries, E.F.J. Brain-derived neurotrophic factor in brain disorders: Focus on neuroinflammation. Mol. Neurobiol. 2019, 56, 3295-3312. [CrossRef] [PubMed]

86. Encinas, M.; Iglesias, M.; Llecha, N.; Comella, J.X. Extracellular-regulated kinases and phosphatidylinositol 3-kinase are involved in brain-derived neurotrophic factor-mediated survival and neuritogenesis of the neuroblastoma cell line SH-SY5Y. J. Neurochem. 1999, 73, 1409-1421. [CrossRef]

87. Boyd, J.G.; Gordon, T. Neurotrophic factors and their receptors in axonal regeneration and functional recovery after peripheral nerve injury. Mol. Neurobiol. 2003, 27, 277-324. [CrossRef]

88. Pang, P.T.; Lu, B. Regulation of late-phase LTP and long-term memory in normal and aging hippocampus: Role of secreted proteins tPA and BDNF. Ageing Res. Rev. 2004, 3, 407-430. [CrossRef]

89. Gustafsson, D.; Klang, A.; Thams, S.; Rostami, E. The role of BDNF in experimental and clinical traumatic brain injury. Int. J. Mol. Sci. 2021, 22, 3582. [CrossRef]

90. Finan, J.D.; Udani, S.V.; Patel, V.; Bailes, J.E. The influence of the Val66Met polymorphism of brain-derived neurotrophic factor on neurological function after traumatic brain injury. J. Alzheimers Dis. 2018, 65, 1055-1064. [CrossRef]

91. Zeiler, F.A.; McFadyen, C.; Newcombe, V.F.J.; Synnot, A.; Donoghue, E.L.; Ripatti, S.; Steyerberg, E.W.; Gruen, R.L.; McAllister, T.W.; Rosand, J.; et al. Genetic influences on patient-oriented outcomes in traumatic brain injury: A systematic review of non-apolipoprotein E single-nucleotide polymorphisms. J. Neurotrauma 2021, 38, 1107-1123. [CrossRef] [PubMed]

92. Giarratana, A.O.; Teng, S.; Reddi, S.; Zheng, C.; Adler, D.; Thakker-Varia, S.; Alder, J. BDNF Val66Met genetic polymorphism results in poor recovery following repeated mild traumatic brain injury in a mouse model and treatment with AAV-BDNF improves outcomes. Front. Neurol. 2019, 10, 1175. [CrossRef] [PubMed]

93. Verhagen, M.; van der Meij, A.; van Deurzen, P.A.; Janzing, J.G.; Arias-Vasquez, A.; Buitelaar, J.K.; Franke, B. Meta-analysis of the BDNF Val66Met polymorphism in major depressive disorder: Effects of gender and ethnicity. Mol. Psychiatry 2010, 15, $260-271$. [CrossRef]

94. Egan, M.F.; Kojima, M.; Callicott, J.H.; Goldberg, T.E.; Kolachana, B.S.; Bertolino, A.; Zaitsev, E.; Gold, B.; Goldman, D.; Dean, M.; et al. The BDNF val66met polymorphism affects activity-dependent secretion of BDNF, human memory, and hippocampal function. Cell 2003, 112, 257-269. [CrossRef]

95. Poo, M.M. Neurotrophins as synaptic modulators. Nat. Rev. Neurosci. 2001, 2, 24-32. [CrossRef] [PubMed]

96. Wang, Y.J.; Chen, K.Y.; Kuo, L.N.; Wang, W.C.; Hsu, Y.W.; Wong, H.S.; Lin, C.M.; Liao, K.H.; Zhang, Y.F.; Chiang, Y.H.; et al. Association between BDNF Val66Met polymorphism and emotional symptoms after mild traumatic brain injury. BMC Med. Genet. 2018, 19, 13. [CrossRef]

97. Krueger, F.; Pardini, M.; Huey, E.D.; Raymont, V.; Solomon, J.; Lipsky, R.H.; Hodgkinson, C.A.; Goldman, D.; Grafman, J. The role of the Met66 brain-derived neurotrophic factor allele in the recovery of executive function after combat-related traumatic brain injury. J. Neurosci. 2011, 31, 598-606. [CrossRef] [PubMed]

98. Barbey, A.K.; Colom, R.; Paul, E.; Forbes, C.; Krueger, F.; Goldman, D.; Grafman, J. Preservation of general intelligence following traumatic brain injury: Contributions of the Met66 brain-derived neurotrophic factor. PLoS ONE 2014, 9, e88733. [CrossRef]

99. Hohn, A.; Leibrock, J.; Bailey, K.; Barde, Y.A. Identification and characterization of a novel member of the nerve growth factor/brain-derived neurotrophic factor family. Nature 1990, 344, 339-341. [CrossRef] [PubMed] 
100. Maness, L.M.; Kastin, A.J.; Weber, J.T.; Banks, W.A.; Beckman, B.S.; Zadina, J.E. Neurotrophins and their receptors: Structure, function, and neuropathology. Neurosci. Biobehav. Rev. 1994, 18, 143-159. [CrossRef]

101. Rosenthal, A.; Goeddel, D.V.; Nguyen, T.; Lewis, M.; Shih, A.; Laramee, G.R.; Nikolics, K.; Winslow, J.W. Primary structure and biological activity of a novel human neurotrophic factor. Neuron 1990, 4, 767-773. [CrossRef]

102. Gong, Y.; Cao, P.; Yu, H.J.; Jiang, T. Crystal structure of the neurotrophin-3 and p75NTR symmetrical complex. Nature 2008, 454, 789-793. [CrossRef]

103. Ernfors, P.; Ibanez, C.F.; Ebendal, T.; Olson, L.; Persson, H. Molecular cloning and neurotrophic activities of a protein with structural similarities to nerve growth factor: Developmental and topographical expression in the brain. Proc. Natl. Acad. Sci. USA 1990, 87, 5454-5458. [CrossRef]

104. Maisonpierre, P.C.; Belluscio, L.; Squinto, S.; Ip, N.Y.; Furth, M.E.; Lindsay, R.M.; Yancopoulos, G.D. Neurotrophin-3: A neurotrophic factor related to NGF and BDNF. Science 1990, 247, 1446-1451. [CrossRef]

105. Ghosh, A.; Greenberg, M.E. Distinct roles for bFGF and NT-3 in the regulation of cortical neurogenesis. Neuron 1995, 15, 89-103. [CrossRef]

106. Lamballe, F.; Klein, R.; Barbacid, M. TrkC, a new member of the Trk family of tyrosine protein kinases, is a receptor for neurotrophin-3. Cell 1991, 66, 967-979. [CrossRef]

107. Akyol, O.; Sherchan, P.; Yilmaz, G.; Reis, C.; Ho, W.M.; Wang, Y.; Huang, L.; Solaroglu, I.; Zhang, J.H. Neurotrophin-3 provides neuroprotection via TrkC receptor-dependent pErk5 activation in a rat surgical brain injury model. Exp. Neurol. 2018, 307, 82-89. [CrossRef]

108. Yang, J.T.; Lee, T.H.; Weng, H.H.; Chang, C.N.; Chen, W.C.; Cheng, W.C.; Wu, J.H. Dexamethasone enhances NT-3 expression in rat hippocampus after traumatic brain injury. Exp. Neurol. 2005, 192, 437-443. [CrossRef]

109. Houlton, J.; Abumaria, N.; Hinkley, S.F.R.; Clarkson, A.N. Therapeutic potential of neurotrophins for repair after brain injury: A helping hand from biomaterials. Front. Neurosci. 2019, 13, 790. [CrossRef] [PubMed]

110. Bates, B.; Hirt, L.; Thomas, S.S.; Akbarian, S.; Le, D.; Amin-Hanjani, S.; Whalen, M.; Jaenisch, R.; Moskowitz, M.A. Neurotrophin-3 promotes cell death induced in cerebral ischemia, oxygen-glucose deprivation, and oxidative stress: Possible involvement of oxygen free radicals. Neurobiol. Dis. 2002, 9, 24-37. [CrossRef]

111. Giehl, K.M.; Tetzlaff, W. BDNF and NT-3, but not NGF, prevent axotomy-induced death of rat corticospinal neurons in vivo. Eur. J. Neurosci. 1996, 8, 1167-1175. [CrossRef] [PubMed]

112. Chaudhry, V.; Giuliani, M.; Petty, B.G.; Lee, D.; Seyedsadr, M.; Hilt, D.; Cornblath, D.R. Tolerability of recombinant-methionyl human neurotrophin-3 (r-metHuNT3) in healthy subjects. Muscle Nerve 2000, 23, 189-192. [CrossRef]

113. Sahenk, Z.; Nagaraja, H.N.; McCracken, B.S.; King, W.M.; Freimer, M.L.; Cedarbaum, J.M.; Mendell, J.R. NT-3 promotes nerve regeneration and sensory improvement in CMT1A mouse models and in patients. Neurology 2005, 65, 681-689. [CrossRef]

114. Barde, Y.A. Trophic factors and neuronal survival. Neuron 1989, 2, 1525-1534. [CrossRef]

115. Thoenen, H. Changes in the expression of neurotrophic factors. Trends Neurosci. 1991, 14, 165-170. [CrossRef]

116. Persson, H.; Ibanez, C.F. Role and expression of neurotrophins and the trk family of tyrosine kinase receptors in neural growth and rescue after injury. Curr. Opin. Neurol. Neurosurg. 1993, 6, 11-18. [PubMed]

117. Timmusk, T.; Belluardo, N.; Metsis, M.; Persson, H. Widespread and developmentally regulated expression of neurotrophin-4 mRNA in rat brain and peripheral tissues. Eur. J. Neurosci. 1993, 5, 605-613. [CrossRef]

118. Wang, T.; Zhang, J.; Li, P.; Ding, Y.; Tang, J.; Chen, G.; Zhang, J.H. NT-4 attenuates neuroinflammation via the TrkB/PI3K/FoxO1 pathway after germinal matrix hemorrhage in neonatal rats. J. Neuroinflam. 2020, 17, 158. [CrossRef]

119. Cheng, B.; Goodman, Y.; Begley, J.G.; Mattson, M.P. Neurotrophin-4/5 protects hippocampal and cortical neurons against energy deprivation- and excitatory amino acid-induced injury. Brain Res. 1994, 650, 331-335. [CrossRef]

120. Cheng, B.; Mattson, M.P. NGF and bFGF protect rat hippocampal and human cortical neurons against hypoglycemic damage by stabilizing calcium homeostasis. Neuron 1991, 7, 1031-1041. [CrossRef]

121. Royo, N.C.; LeBold, D.; Magge, S.N.; Chen, I.; Hauspurg, A.; Cohen, A.S.; Watson, D.J. Neurotrophin-mediated neuroprotection of hippocampal neurons following traumatic brain injury is not associated with acute recovery of hippocampal function. Neuroscience 2007, 148, 359-370. [CrossRef]

122. Mao, X.; Hao, S.; Zhu, Z.; Zhang, H.; Wu, W.; Xu, F.; Liu, B. Procyanidins protects against oxidative damage and cognitive deficits after traumatic brain injury. Brain Inj. 2015, 29, 86-92. [CrossRef]

123. Wu, A.; Ying, Z.; Gomez-Pinilla, F. The interplay between oxidative stress and brain-derived neurotrophic factors modulates the outcome of a saturated fat diet on synaptic plasticity and cognition. Eur. J. Neurosci. 2004, 19, 1699-1707. [CrossRef] [PubMed]

124. Krishna, G.; Ying, Z.; Gomez-Pinilla, F. Blueberry supplementation mitigates altered brain plasticity and behavior after traumatic brain injury in rats. Mol. Nutr. Food Res. 2019, 63, e1801055. [CrossRef] [PubMed]

125. Wu, A.; Ying, Z.; Gomez-Pinilla, F. Salutary effects of DHA dietary supplementation on cognition, neuroplasticity, and membrane homeostasis after brain trauma. J. Neurotrauma 2011, 28, 2113-2122. [CrossRef] [PubMed]

126. Ying, Z.; Feng, C.; Agrawal, R.; Zhuang, Y.; Gomez-Pinilla, F. Dietary omega-3 deficiency from gestation increases spinal cord vulnerability to traumatic brain injury-induced damage. PLoS ONE 2012, 7, e52998. [CrossRef] [PubMed]

127. Agrawal, R.; Tyagi, E.; Vergnes, L.; Reue, K.; Gomez-Pinilla, F. Coupling energy homeostasis with a mechanism to support plasticity in brain trauma. Biochim. Biophys. Acta 2014, 1842, 535-546. [CrossRef] 
128. Chandrasekar, A.; Aksan, B.; Heuvel, O.; Förstner, P.; Sinske, D.; Rehman, R.; Palmer, A.; Ludolph, A.; Huber-Lang, M.; Böckers, T.; et al. The neuroprotective effect of acute ethanol intoxication in TBI is associated with the hierarchical modulation of early transcriptional responses. Exp. Neurol. 2018, 302, 34-45. [CrossRef]

129. Wu, A.; Ying, Z.; Gomez-Pinilla, F. Dietary curcumin counteracts the outcome of traumatic brain injury on oxidative stress, synaptic plasticity, and cognition. Exp. Neurol. 2006, 197, 309-317. [CrossRef] [PubMed]

130. Rich, N.J.; Van Landingham, J.W.; Figueiroa, S.; Seth, R.; Corniola, R.S.; Levenson, C.W. Chronic caloric restriction reduces tissue damage and improves spatial memory in a rat model of traumatic brain injury. J. Neurosci. Res. 2010, 88, 2933-2939. [CrossRef]

131. Ji, X.; Peng, D.; Zhang, Y.; Zhang, J.; Wang, Y.; Gao, Y.; Lu, N.; Tang, P. Astaxanthin improved cognitive performance in mice following mild traumatic brain injury. Brain Res. 2017, 1659, 88-95. [CrossRef] [PubMed]

132. Zhao, Y.; Lee, J.H.; Chen, D.; Gu, X.; Caslin, A.; Li, J.; Yu, S.P.; Wei, L. DL-3-n-butylphthalide induced neuroprotection, regenerative repair, functional recovery, and psychological benefits following traumatic brain injury in mice. Neurochem. Int. 2017, 111, 82-92. [CrossRef] [PubMed]

133. Ignowski, E.; Winter, A.N.; Duval, N.; Fleming, H.; Wallace, T.; Manning, E.; Koza, L.; Huber, K.; Serkova, N.J.; Linseman, D.A The cysteine-rich whey protein supplement, Immunocal ${ }^{\circledR}$, preserves brain glutathione and improves cognitive, motor, and histopathological indices of traumatic brain injury in a mouse model of controlled cortical impact. Free Radic. Biol. Med. 2018, 124, 328-341. [CrossRef]

134. Ren, Y.Z.; Zhang, B.Z.; Zhao, X.J.; Zhang, Z.Y. Resolvin D1 ameliorates cognitive impairment following traumatic brain injury by protecting astrocytic mitochondria. J. Neurochem. 2020, 154, 530-546. [CrossRef]

135. Portbury, D.D.; Hare, D.J.; Finkelstein, D.I.; Adlard, P.A. Trehalose improves traumatic brain injury-induced cognitive impairment. PLoS ONE 2017, 12, e0183683. [CrossRef]

136. Aiguo, W.; Zhe, Y.; Gomez-Pinilla, F. Vitamin E protects against oxidative damage and learning disability after mild traumatic brain injury in rats. Neurorehabil. Neural Repair 2010, 24, 290-298. [CrossRef]

137. Reyes-Izquierdo, T.; Nemzer, B.; Shu, C.; Huynh, L.; Argumedo, R.; Keller, R.; Pietrzkowski, Z. Modulatory effect of coffee fruit extract on plasma levels of brain-derived neurotrophic factor in healthy subjects. Br. J. Nutr. 2013, 110, 420-425. [CrossRef]

138. Frautschy, S.A.; Hu, W.; Kim, P.; Miller, S.A.; Chu, T.; Harris-White, M.E.; Cole, G.M. Phenolic anti-inflammatory antioxidant reversal of Abeta-induced cognitive deficits and neuropathology. Neurobiol. Aging 2001, 22, 993-1005. [CrossRef]

139. Grey, V.; Mohammed, S.R.; Smountas, A.A.; Bahlool, R.; Lands, L.C. Improved glutathione status in young adult patients with cystic fibrosis supplemented with whey protein. J. Cyst. Fibros. 2003, 2, 195-198. [CrossRef]

140. Colcombe, S.; Kramer, A.F. Fitness effects on the cognitive function of older adults: A meta-analytic study. Psychol. Sci. 2003, 14, 125-130. [CrossRef]

141. Etnier, J.L.; Nowell, P.M.; Landers, D.M.; Sibley, B.A. Meta-regression was used to examine the relationship between aerobic fitness and cognitive performance. Brain Res. Rev. 2006, 52, 119-130. [CrossRef]

142. Hoyland, A.; Dye, L.; Lawton, C.L. A systematic review of the effect of breakfast on cognitive performance in children and adolescents. Nutr. Res. Rev. 2009, 22, 220-243. [CrossRef]

143. Knaepen, K.; Goekint, M.; Heyman, E.M.; Meeusen, R. Neuroplasticity-exercise-induced response of peripheral brain-derived neurotrophic factor: A systematic review of experimental studies in human subjects. Sports Med. 2010, 40, 765-801. [CrossRef]

144. Cassilhas, R.C.; Viana, V.A.; Grassmann, V.; Santos, R.T.; Santos, R.F.; Tufik, S.; Mello, M.T. The impact of resistance exercise on cognitive function in the elderly. Med. Sci. Sports Exerc. 2007, 39, 1401-1407. [CrossRef] [PubMed]

145. Martinez-Drudis, L.; Amoros-Aguilar, L.; Torras-Garcia, M.; Serra-Elias, B.; Costa-Miserachs, D.; Portell-Cortes, I.; Coll-Andreu, M. Delayed voluntary physical exercise restores "when" and "where" object recognition memory after traumatic brain injury. Behav. Brain Res. 2021, 400, 113048. [CrossRef] [PubMed]

146. Chou, W.; Liu, Y.F.; Lin, C.H.; Lin, M.T.; Chen, C.C.; Liu, W.P.; Chang, C.P.; Chio, C.C. Exercise rehabilitation attenuates cognitive deficits in rats with traumatic brain injury by stimulating the cerebral HSP20/BDNF/TrkB signaling axis. Mol. Neurobiol. 2018, 55, 8602-8611. [CrossRef]

147. Griesbach, G.S.; Gomez-Pinilla, F.; Hovda, D.A. The upregulation of plasticity-related proteins following TBI is disrupted by acute voluntary exercise. Brain Res. 2004, 1016, 154-162. [CrossRef]

148. Chytrova, G.; Ying, Z.; Gomez-Pinilla, F. Exercise normalized levels of MAG and Nogo-A growth inhibitors after brain trauma. Eur. J. Neurosci. 2008, 27, 1-11. [CrossRef] [PubMed]

149. Griesbach, G.S.; Hovda, D.A.; Gomez-Pinilla, F.; Sutton, R.L. Voluntary exercise or amphetamine treatment, but not the combination, increases hippocampal brain-derived neurotrophic factor and synapsin I following cortical contusion injury in rats. Neuroscience 2008, 154, 530-540. [CrossRef]

150. Griesbach, G.S.; Hovda, D.A.; Gomez-Pinilla, F. Exercise-induced improvement in cognitive performance after traumatic brain injury in rats is dependent on BDNF activation. Brain Res. 2009, 1288, 105-115. [CrossRef] [PubMed]

151. Wu, A.; Ying, Z.; Gomez-Pinilla, F. Exercise facilitates the action of dietary DHA on functional recovery after brain trauma. Neuroscience 2013, 248, 655-663. [CrossRef] [PubMed]

152. Hicks, R.R.; Boggs, A.; Leider, D.; Kraemer, P.; Brown, R.; Scheff, S.W.; Seroogy, K.B. Effects of exercise following lateral fluid percussion brain injury in rats. Restor. Neurol. Neurosci. 1998, 12, 41-47. [PubMed] 
153. Shin, M.S.; Park, H.K.; Kim, T.W.; Ji, E.S.; Lee, J.M.; Choi, H.S.; Kim, M.Y.; Kim, Y.P. Neuroprotective effects of bone marrow stromal cell transplantation in combination with treadmill exercise following traumatic brain injury. Int. Neurourol. J. 2016, 20, S49-S56. [CrossRef] [PubMed]

154. Griesbach, G.S.; Tio, D.L.; Vincelli, J.; McArthur, D.L.; Taylor, A.N. Differential effects of voluntary and forced exercise on stress responses after traumatic brain injury. J. Neurotrauma 2012, 29, 1426-1433. [CrossRef] [PubMed]

155. Griesbach, G.S.; Tio, D.L.; Nair, S.; Hovda, D.A. Recovery of stress response coincides with responsiveness to voluntary exercise after traumatic brain injury. J. Neurotrauma 2014, 31, 674-682. [CrossRef] [PubMed]

156. Shen, X.; Li, A.; Zhang, Y.; Dong, X.; Shan, T.; Wu, Y.; Jia, J.; Hu, Y. The effect of different intensities of treadmill exercise on cognitive function deficits following a severely controlled cortical impact in rats. Int. J. Mol. Sci. 2013, 14, 21598-21612. [CrossRef]

157. Chen, M.F.; Huang, Y.Y.; Kuo, M.; Yu, L.; Chen, H.I.; Jen, J.C. Early post-injury exercise reverses memory deficits and retards the progression of closed-head injury in mice. J. Physiol. 2013, 591, 985-1000. [CrossRef]

158. Griesbach, G.S.; Gomez-Pinilla, F.; Hovda, D.A. Time window for voluntary exercise-induced increases in hippocampal neuroplasticity molecules after traumatic brain injury is severity-dependent. J. Neurotrauma 2007, 24, 1161-1171. [CrossRef]

159. Alison, M.R.; Poulsom, R.; Forbes, S.; Wright, N.A. Introduction to stem cells. J. Pathol. 2002, 197, 419-423. [CrossRef]

160. Aly, R.M. Current state of stem cell-based therapies: An overview. Stem Cell Investig. 2020, 7, 8. [CrossRef]

161. Kulbatski, I.; Mothe, A.J.; Nomura, H.; Tator, C.H. Endogenous and exogenous CNS derived stem/progenitor cell approaches for neurotrauma. Curr. Drug Targets 2005, 6, 111-126. [CrossRef]

162. Choumerianou, D.M.; Dimitriou, H.; Kalmanti, M. Stem cells: Promises versus limitations. Tissue Eng. Part B Rev. 2008, 14, 53-60. [CrossRef] [PubMed]

163. Deng, Q.J.; Xu, X.F.; Ren, J. Effects of SDF-1/CXCR4 on the repair of traumatic brain injury in rats by mediating bone marrow derived mesenchymal stem cells. Cell Mol. Neurobiol. 2018, 38, 467-477. [CrossRef] [PubMed]

164. Mahmood, A.; Lu, D.; Chopp, M. Intravenous administration of marrow stromal cells (MSCs) increases the expression of growth factors in the rat brain after traumatic brain injury. J. Neurotrauma 2004, 21, 33-39. [CrossRef]

165. Feng, Y.; Ju, Y.; Cui, J.; Wang, L. Bone marrow stromal cells promote neuromotor functional recovery via upregulation of neurotrophic factors and synapse proteins following traumatic brain injury in rats. Mol. Med. Rep. 2017, 16, 654-660. [CrossRef] [PubMed]

166. Mahmood, A.; Lu, D.; Qu, C.; Goussev, A.; Chopp, M. Long-term recovery after bone marrow stromal cell treatment of traumatic brain injury in rats. J. Neurosurg. 2006, 104, 272-277. [CrossRef] [PubMed]

167. Wu, K.; Huang, D.; Zhu, C.; Kasanga, E.A.; Zhang, Y.; Yu, E.; Zhang, H.; Ni, Z.; Ye, S.; Zhang, C.; et al. NT3(P75-2) gene-modified bone mesenchymal stem cells improve neurological function recovery in a mouse model of TBI. Stem Cell Res. $2019,10,311$. [CrossRef]

168. Cheng, T.; Yang, B.; Li, D.; Ma, S.; Tian, Y.; Qu, R.; Zhang, W.; Zhang, Y.; Hu, K.; Guan, F.; et al. Wharton's jelly transplantation improved neurological function in a rat model of traumatic brain injury. Cell Mol. Neurobiol. 2015, 35, 641-649. [CrossRef]

169. Kim, H.J.; Lee, J.H.; Kim, S.H. Therapeutic effects of human mesenchymal stem cells on traumatic brain injury in rats: Secretion of neurotrophic factors and inhibition of apoptosis. J. Neurotrauma 2010, 27, 131-138. [CrossRef]

170. Xu, H.; Jia, Z.; Ma, K.; Zhang, J.; Dai, C.; Yao, Z.; Deng, W.; Su, J.; Wang, R.; Chen, X. Protective effect of BMSCs-derived exosomes mediated by BDNF on TBI via miR-216a-5p. Med. Sci. Monit. 2020, 26, e920855. [CrossRef]

171. Bonilla, C.; Zurita, M.; Aguayo, C.; Rodriguez, A.; Vaquero, J. Is the subarachnoid administration of mesenchymal stromal cells a useful strategy to treat chronic brain damage? Cytotherapy 2014, 16, 1501-1510. [CrossRef]

172. Das, M.; Mayilsamy, K.; Tang, X.; Han, J.Y.; Foran, E.; Willing, A.E.; Mohapatra, S.S.; Mohapatra, S. Pioglitazone treatment prior to transplantation improves the efficacy of human mesenchymal stem cells after traumatic brain injury in rats. Sci. Rep. 2019, 9, 13646. [CrossRef] [PubMed]

173. Xiong, L.L.; Hu, Y.; Zhang, P.; Zhang, Z.; Li, L.H.; Gao, G.D.; Zhou, X.F.; Wang, T.H. Neural stem cell transplantation promotes functional recovery from traumatic brain injury via brain derived neurotrophic factor-mediated neuroplasticity. Mol. Neurobiol. 2018, 55, 2696-2711. [CrossRef]

174. Yan, Z.J.; Zhang, P.; Hu, Y.Q.; Zhang, H.T.; Hong, S.Q.; Zhou, H.L.; Zhang, M.Y.; Xu, R.X. Neural stem-like cells derived from human amnion tissue are effective in treating traumatic brain injury in rat. Neurochem. Res. 2013, 38, 1022-1033. [CrossRef] [PubMed]

175. Shindo, T.; Matsumoto, Y.; Wang, Q.; Kawai, N.; Tamiya, T.; Nagao, S. Differences in the neuronal stem cells survival, neuronal differentiation and neurological improvement after transplantation of neural stem cells between mild and severe experimental traumatic brain injury. J. Med. Investig. 2006, 53, 42-51. [CrossRef] [PubMed]

176. Ma, H.; Yu, B.; Kong, L.; Zhang, Y.; Shi, Y. Neural stem cells over-expressing brain-derived neurotrophic factor (BDNF) stimulate synaptic protein expression and promote functional recovery following transplantation in rat model of traumatic brain injury. Neurochem. Res. 2012, 37, 69-83. [CrossRef]

177. Chen, T.; Wu, Y.; Wang, Y.; Zhu, J.; Chu, H.; Kong, L.; Yin, L.; Ma, H. Brain-derived neurotrophic factor increases synaptic protein levels via the MAPK/Erk signaling pathway and Nrf2/Trx axis following the transplantation of neural stem cells in a rat model of traumatic brain injury. Neurochem. Res. 2017, 42, 3073-3083. [CrossRef]

178. Qi, L.; Xue, X.; Sun, J.; Wu, Q.; Wang, H.; Guo, Y.; Sun, B. The promising effects of transplanted umbilical cord mesenchymal stem cells on the treatment in traumatic brain injury. J. Craniofac. Surg. 2018, 29, 1689-1692. [CrossRef] [PubMed] 
179. Shi, W.; Nie, D.; Jin, G.; Chen, W.; Xia, L.; Wu, X.; Su, X.; Xu, X.; Ni, L.; Zhang, X.; et al. BDNF blended chitosan scaffolds for human umbilical cord MSC transplants in traumatic brain injury therapy. Biomaterials 2012, 33, 3119-3126. [CrossRef]

180. Wang, Y.; Peng, D.; Yang, X.; Huang, P.; Ye, H.; Hui, Y.; Wang, X.; Sun, W.; Wu, H.; Zhang, S.; et al. Study on umbilical cord-matrix stem cells transplantation for treatment of acute traumatic brain injury in rats. Turk. Neurosurg. 2019, 29, 750-758. [CrossRef]

181. Gincberg, G.; Shohami, E.; Trembovler, V.; Alexandrovich, A.G.; Lazarovici, P.; Elchalal, U. Nerve growth factor plays a role in the neurotherapeutic effect of a CD45(+) pan-hematopoietic subpopulation derived from human umbilical cord blood in a traumatic brain injury model. Cytotherapy 2018, 20, 245-261. [CrossRef]

182. Barretto, T.A.; Park, K.; Maghen, L.; Park, E.; Kenigsberg, S.; Gallagher, D.; Liu, E.; Gauthier-Fisher, A.; Librach, C.; Baker, A. Axon degeneration is rescued with human umbilical cord perivascular cells: A potential candidate for neuroprotection after traumatic brain injury. Stem Cells Dev. 2020, 29, 198-211. [CrossRef]

183. Shi, W.; Huang, C.J.; Xu, X.D.; Jin, G.H.; Huang, R.Q.; Huang, J.F.; Chen, Y.N.; Ju, S.Q.; Wang, Y.; Shi, Y.W.; et al. Transplantation of RADA16-BDNF peptide scaffold with human umbilical cord mesenchymal stem cells forced with CXCR4 and activated astrocytes for repair of traumatic brain injury. Acta Biomater. 2016, 45, 247-261. [CrossRef]

184. Luo, M.L.; Pan, L.; Wang, L.; Wang, H.Y.; Li, S.; Long, Z.Y.; Zeng, L.; Liu, Y. Transplantation of NSCs promotes the recovery of cognitive functions by regulating neurotransmitters in rats with traumatic brain injury. Neurochem. Res. 2019, 44, $2765-2775$. [CrossRef] [PubMed]

185. Wang, E.; Gao, J.; Yang, Q.; Parsley, M.O.; Dunn, T.J.; Zhang, L.; DeWitt, D.S.; Denner, L.; Prough, D.S.; Wu, P. Molecular mechanisms underlying effects of neural stem cells against traumatic axonal injury. J. Neurotrauma 2012, 29, 295-312. [CrossRef] [PubMed]

186. Blaya, M.O.; Tsoulfas, P.; Bramlett, H.M.; Dietrich, W.D. Neural progenitor cell transplantation promotes neuroprotection, enhances hippocampal neurogenesis, and improves cognitive outcomes after traumatic brain injury. Exp. Neurol. 2015, $264,67-81$. [CrossRef]

187. Shaito, A.; Hasan, H.; Habashy, K.J.; Fakih, W.; Abdelhady, S.; Ahmad, F.; Zibara, K.; Eid, A.H.; El-Yazbi, A.F.; Kobeissy, F.H. Western diet aggravates neuronal insult in post-traumatic brain injury: Proposed pathways for interplay. EBioMedicine 2020, 57, 102829. [CrossRef] [PubMed]

188. Bullock, R.; Zauner, A.; Woodward, J.J.; Myseros, J.; Choi, S.C.; Ward, J.D.; Marmarou, A.; Young, H.F. Factors affecting excitatory amino acid release following severe human head injury. J. Neurosurg. 1998, 89, 507-518. [CrossRef]

189. McGinn, M.J.; Povlishock, J.T. Pathophysiology of Traumatic Brain Injury. Neurosurg. Clin. N. Am. 2016, 27, 397-407. [CrossRef]

190. Wu, H.M.; Huang, S.C.; Hattori, N.; Glenn, T.C.; Vespa, P.M.; Hovda, D.A.; Bergsneider, M. Subcortical white matter metabolic changes remote from focal hemorrhagic lesions suggest diffuse injury after human traumatic brain injury. Neurosurgery 2004, 55, 1306-1315. [CrossRef]

191. Bergsneider, M.; Hovda, D.A.; Shalmon, E.; Kelly, D.F.; Vespa, P.M.; Martin, N.A.; Phelps, M.E.; McArthur, D.L.; Caron, M.J.; Kraus, J.F.; et al. Cerebral hyperglycolysis following severe traumatic brain injury in humans: A positron emission tomography study. J. Neurosurg. 1997, 86, 241-251. [CrossRef]

192. Kawamata, T.; Katayama, Y.; Hovda, D.A.; Yoshino, A.; Becker, D.P. Administration of excitatory amino acid antagonists via microdialysis attenuates the increase in glucose utilization seen following concussive brain injury. J. Cereb. Blood Flow Metab. 1992, 12, 12-24. [CrossRef]

193. Bergsneider, M.; Hovda, D.A.; Lee, S.M.; Kelly, D.F.; McArthur, D.L.; Vespa, P.M.; Lee, J.H.; Huang, S.C.; Martin, N.A.; Phelps, M.E.; et al. Dissociation of cerebral glucose metabolism and level of consciousness during the period of metabolic depression following human traumatic brain injury. J. Neurotrauma 2000, 17, 389-401. [CrossRef]

194. Giza, C.C.; Hovda, D.A. The Neurometabolic Cascade of Concussion. J. Athl. Train. 2001, 36, 228-235. [CrossRef] [PubMed]

195. Carre, E.; Ogier, M.; Boret, H.; Montcriol, A.; Bourdon, L.; Jean-Jacques, R. Metabolic crisis in severely head-injured patients: Is ischemia just the tip of the iceberg? Front. Neurol. 2013, 4, 146. [CrossRef] [PubMed]

196. Leung, L.Y.; Deng-Bryant, Y.; Cardiff, K.; Winter, M.; Tortella, F.; Shear, D. Neurochemical changes following combined hypoxemia and hemorrhagic shock in a rat model of penetrating ballistic-like brain injury: A microdialysis study. J. Trauma Acute Care Surg. 2016, 81, 860-867. [CrossRef] [PubMed]

197. DeVience, S.J.; Lu, X.; Proctor, J.; Rangghran, P.; Melhem, E.R.; Gullapalli, R.; Fiskum, G.M.; Mayer, D. Metabolic imaging of energy metabolism in traumatic brain injury using hyperpolarized [1-(13)C]pyruvate. Sci. Rep. 2017, 7, 1907. [CrossRef]

198. Vespa, P.; Bergsneider, M.; Hattori, N.; Wu, H.M.; Huang, S.C.; Martin, N.A.; Glenn, T.C.; McArthur, D.L.; Hovda, D.A. Metabolic crisis without brain ischemia is common after traumatic brain injury: A combined microdialysis and positron emission tomography study. J. Cereb. Blood Flow Metab. 2005, 25, 763-774. [CrossRef] [PubMed]

199. Werner, C.; Engelhard, K. Pathophysiology of traumatic brain injury. Br. J. Anaesth. 2007, 99, 4-9. [CrossRef]

200. Da Silva Meirelles, L.; Simon, D.; Regner, A. Neurotrauma: The Crosstalk between Neurotrophins and Inflammation in the Acutely Injured Brain. Int. J. Mol. Sci. 2017, 18, 1082. [CrossRef]

201. Nakagawa, T.; Tsuchida, A.; Itakura, Y.; Nonomura, T.; Ono, M.; Hirota, F.; Inoue, T.; Nakayama, C.; Taiji, M.; Noguchi, H. Brain-derived neurotrophic factor regulates glucose metabolism by modulating energy balance in diabetic mice. Diabetes 2000, 49 , 436-444. [CrossRef]

202. Wang, C.; Bomberg, E.; Billington, C.; Levine, A.; Kotz, C.M. Brain-derived neurotrophic factor in the hypothalamic paraventricular nucleus reduces energy intake. Am. J. Physiol. Regul. Integr. Comp. Physiol. 2007, 293, R1003-R1012. [CrossRef] 
203. Cao, L.; Choi, E.Y.; Liu, X.; Martin, A.; Wang, C.; Xu, X.; During, M.J. White to brown fat phenotypic switch induced by genetic and environmental activation of a hypothalamic-adipocyte axis. Cell Metab. 2011, 14, 324-338. [CrossRef] [PubMed]

204. Griffioen, K.J.; Wan, R.; Brown, T.R.; Okun, E.; Camandola, S.; Mughal, M.R.; Phillips, T.M.; Mattson, M.P. Aberrant heart rate and brainstem brain-derived neurotrophic factor (BDNF) signaling in a mouse model of Huntington's disease. Neurobiol. Aging 2012, 33, 1481.e1-1481.e5. [CrossRef] [PubMed]

205. Guo, X.; Jiang, Q.; Tuccitto, A.; Chan, D.; Alqawlaq, S.; Won, G.J.; Sivak, J.M. The AMPK-PGC-1alpha signaling axis regulates the astrocyte glutathione system to protect against oxidative and metabolic injury. Neurobiol. Dis. 2018, 113, 59-69. [CrossRef]

206. Rothman, S.M.; Griffioen, K.J.; Wan, R.; Mattson, M.P. Brain-derived neurotrophic factor as a regulator of systemic and brain energy metabolism and cardiovascular health. Ann. N. Y. Acad. Sci. 2012, 1264, 49-63. [CrossRef] [PubMed]

207. Cordeira, J.W.; Frank, L.; Sena-Esteves, M.; Pothos, E.N.; Rios, M. Brain-derived neurotrophic factor regulates hedonic feeding by acting on the mesolimbic dopamine system. J. Neurosci. 2010, 30, 2533-2541. [CrossRef] [PubMed] 